\title{
GROUND-WATER FLOW AND THE POTENTIAL EFFECTS \\ OF REMEDIATION AT GRACES QUARTERS, ABERDEEN \\ PROVING GROUND, MARYLAND
}

\section{U.S. GEOLOGICAL SURVEY}

Water-Resources Investigations Report 96-4044

Prepared in cooperation with the

U.S. ARMY ABERDEEN PROVING GROUND SUPPORT ACTIVITY

ENVIRONMENTAL CONSERVATION AND RESTORATION DIVISION ABERDEEN PROVING GROUND, MARYLAND 
CONVERSION FACTORS AND VERTICAL DATUM

\begin{tabular}{|c|c|c|}
\hline Multiply & By & To obtain \\
\hline foot $(f t)$ & 0.3048 & meter \\
\hline acre & 4047 & square meter \\
\hline acre & 0.4047 & hectare \\
\hline foot per day $(\mathrm{ft} / \mathrm{d})$ & 0.3048 & meter per day \\
\hline square foot per day $\left(\mathrm{ft}^{2} / \mathrm{d}\right)$ & 0.09290 & square meter per day \\
\hline cubic foot per day $\left(\mathrm{ft}^{3} / \mathrm{d}\right)$ & 0.02832 & cubic meter per day \\
\hline inch per year (in/yr) & 25.4 & millimeter per year \\
\hline gallon per minute (gal/min) & 0.06309 & liters per second \\
\hline
\end{tabular}

Sea level: In this report, "sea level" refers to the National Geodetic Vertical Datum of 1929--a geodetic datum derived from a general adjustment of the first-order level nets of the United States and Canada, formerly called Sea Level Datum of 1929. 


\section{U.S. DEPARTMENT OF THE INTERIOR \\ BRUCE BABBITT, Secretary \\ U.S. GEOLOGICAL SURVEY}

Gordon P. Eaton, Director

For additional information write to:

District Chief

U.S. Geological Survey, WRD

208 Carroll Building

8600 La Salle Road

Towson, MD 21286
Copies of this report can be purchased from:

U.S. Geological Survey

Earth Science Information Center

Open-File Reports Section

Box 25286, MS 517

Denver Federal Center

Denver, CO 80225 


\section{GROUND-WATER FLOW AND THE POTENTIAL EFFECTS OF REMEDIATION AT GRACES QUARTERS, ABERDEEN PROVING GROUND, MARYLAND}

By Frederick J. Tenbus and William B. Fleck

U.S. GEOLOGICAL SURVEY

Water-Resources Investigations Report 96-4044

Prepared in cooperation with the

U.S. ARMY ABERDEEN PROVING GROUND SUPPORT ACTIVITY ENVIRONMENTAL CONSERVATION AND RESTORATION DIVISION ABERDEEN PROVING GROUND, MARYLAND

Towson, Maryland 


\section{CONTENTS}

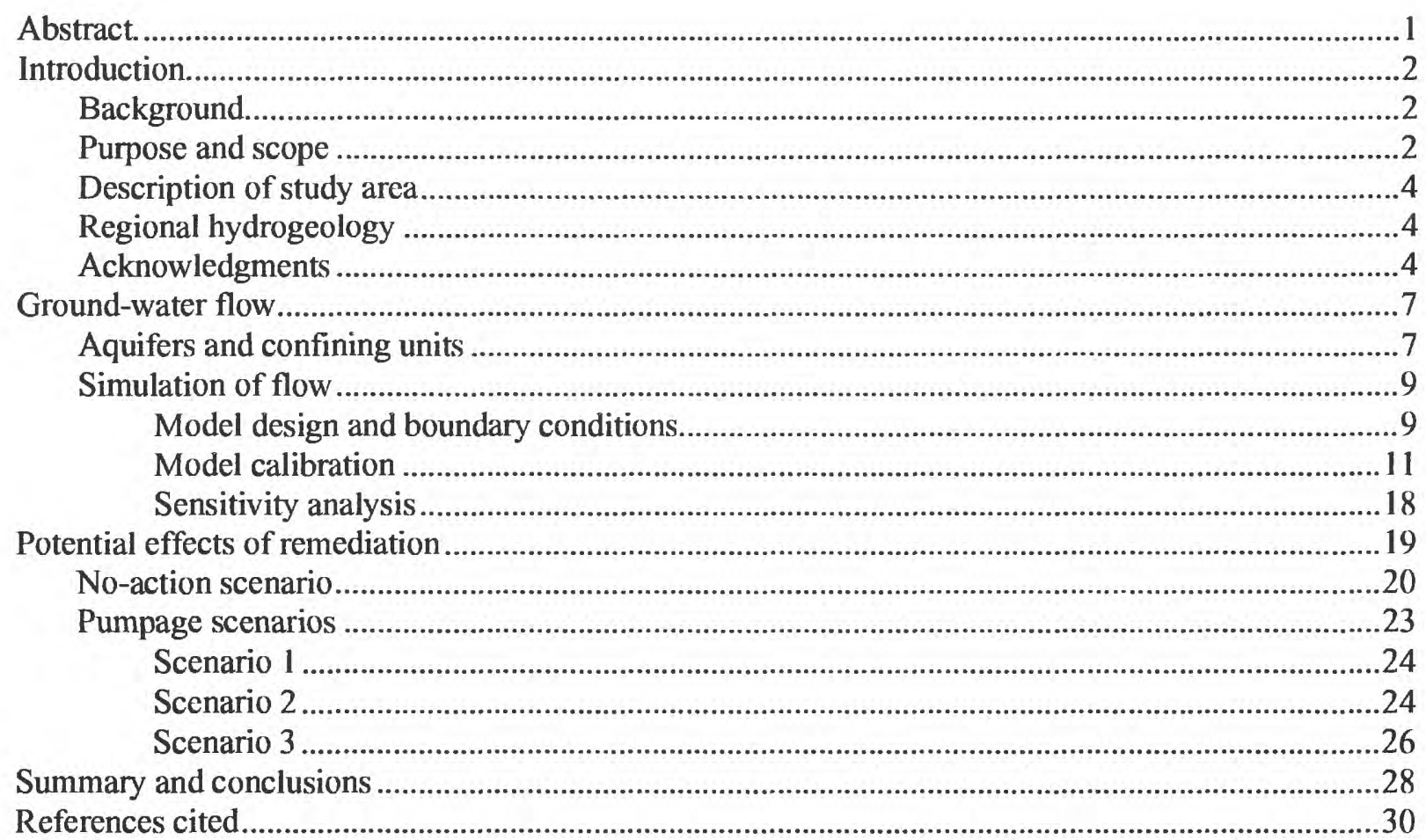

\section{FIGURES}

1-2. Maps showing location of:

1. Graces Quarters study area on Aberdeen Proving Ground near Baltimore, Maryland

2. Roads and selected physiographic features at Graces Quarters, Aberdeen Proving Ground, Maryland.

3. Schematic diagram showing hydrogeologic units and generalized ground-water flow directions at Graces Quarters, Aberdeen Proving Ground, Maryland

4-6. Maps showing:

4. Finite-difference grid and generalized lateral model boundaries ........................................ 10

5. Zones of simulated recharge for the ground-water flow model .............................................. 12

6. Averaged hydraulic head in the surficial aquifer, Graces Quarters, Aberdeen Proving Ground, Maryland, April and July 1994.

7. Graph showing relation between measured and simulated water levels at Graces Quarters, Aberdeen Proving Ground, Maryland. 


\section{FIGURES--Continued}

8. Graph showing sensitivity of simulated hydraulic head to changes in recharge, transmissivity, leakance, and hydraulic conductivity.

9. Map showing simulated hydraulic head in the surficial aquifer and ground-water pathways for conservative transport from contaminated areas under the no-action scenario.

10. Cross sections showing model layers and simulated ground-water pathways for $5,10,25,50,100$, and 200 years of conservative transport from contaminated areas under the no-action scenario

11. Map showing location of simulated extraction wells for pumpage scenarios 1 to 3

12-14. Maps showing locations of simulated extraction wells, hydraulic head in the surficial aquifer, and ground-water pathlines for:

12. Pumpage scenario 1

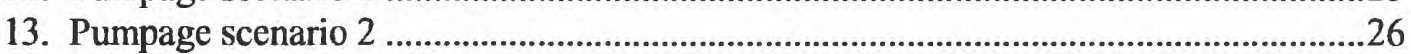

14. Pumpage scenario 3

\section{TABLES}

1. Stratigraphic units, hydrogeologic units, and equivalent model layers or boundary condition in the numerical ground-water flow model, Graces Quarters, Aberdeen Proving Ground, Maryland..

2. Summary of hydraulic conductivity values used to calibrate the ground-water flow model at Graces Quarters, Aberdeen Proving Ground, Maryland

3. Hydraulic conductivity values used in ground-water flow model for indicated letter symbol from Unified Soil Classification System

\section{ACRONYMS AND ABBREVIATIONS}

$\begin{array}{ll}\text { AEC: } & \text { Army Environmental Center (formerly USATHAMA) } \\ \text { APG: } & \text { Aberdeen Proving Ground } \\ \text { CERCLA: } & \text { Comprehensive Environmental Response, Compensation, and Liability Act } \\ \text { HGA: } & \text { Hydrogeologic assessment } \\ \text { ET: } & \text { Evapotranspiration }\end{array}$

MODFLOW: U.S. Geological Survey modular ground-water flow model

RCRA: $\quad$ Resource Conservation and Recovery Act

RI/FS: $\quad$ Remedial Investigation/Feasibility Study

SWMU: $\quad$ Solid waste management unit

USATHAMA U.S. Army Toxic and Hazardous Materials Agency (now known as AEC)

USEPA: $\quad$ U.S. Environmental Protection Agency

USGS: $\quad$ U.S. Geological Survey

VOC: $\quad$ Volatile organic compound 


\title{
GROUND-WATER FLOW AND THE POTENTIAL EFFECTS OF REMEDIATION AT GRACES QUARTERS, ABERDEEN PROVING GROUND, MARYLAND
}

\author{
By Frederick J. Tenbus and William B. Fleck
}

\begin{abstract}
Graces Quarters is a former open-air chemical-agent test facility at Aberdeen Proving Ground (APG), Md. Activities related to testing resulted in ground-water contamination by volatile organic compounds in the east-central part of Graces Quarters. Because of this contamination, APG was required under the Comprehensive Environmental Response, Compensation, and Liability Act to address the feasibility of ground-water cleanup. The U.S. Geological Survey's finite-difference model MODFLOW was used at Graces Quarters to help understand ground-water flow and to simulate the effects of remedial actions. The model consists of five layers, three of which were used to simulate the surficial aquifer, with confining units simulated by leakance between layers. The area modeled is 2.45 square miles, and the model was constructed with a variably-spaced 79 rows by 56 columns grid. Calibration consisted of obtaining estimates of the areal distribution of recharge and hydraulic conductivity and adjusting these variables within reasonable limits such that simulated heads closely match an averaged measured hydraulic head distribution. Scenarios based on the calibrated model to simulate unstressed conditions and three extraction well configurations were used to compare the effects of alternative remedial actions on the distribution of the contaminant plume. The model scenarios indicate that (1) contaminants could migrate from their present location to wetland areas within 10 years under unstressed conditions; (2) pumping $7 \mathrm{gal} / \mathrm{min}$ from one well at a potential source area for the plume will not result in a capture zone of sufficient size to intersect the locations of the highest contaminant concentrations; (3) pumping $7 \mathrm{gal} / \mathrm{min}$ from three wells along the axis of the highest contaminant concentration in the plume should result in containment of the plume and removal of dissolved contaminants; and (4) pumping $7 \mathrm{gal} / \mathrm{min}$ from three wells at the leading edge of the plume and injecting $7 \mathrm{gal} / \mathrm{min}$ back into an upgradient well also should result in containment of the plume and removal of dissolved contaminants.
\end{abstract}




\section{INTRODUCTION}

Graces Quarters is located in the Edgewood Area of Aberdeen Proving Ground (APG), Baltimore County, Md. (fig. 1), and was used as an open-air test site for chemical agents and munitions from the late 1940's to about 1971. Testing and disposal activities during this time resulted in ground-water contamination at Graces Quarters. Because ground-water contamination at this site degrades the waters of the State of Maryland and there is some potential for offsite migration of contaminated ground water, APG investigated the feasibility of remediating ground-water quality at Graces Quarters.

\section{Background}

In 1977 and 1978, Graces Quarters was studied as part of an environmental survey of the Edgewood Area conducted by the U.S. Army Toxic and Hazardous Materials Agency (USATHAMA; now known as the Army Environmental Center, or AEC) (Nemeth and others, 1983). That study resulted in the U.S. Environmental Protection Agency (USEPA) issuing a Resource Conservation and Recovery Act (RCRA) permit (MD3-21-0021355) in 1986. The RCRA permit required that a hydrogeologic assessment (HGA) be done at Graces Quarters.

The U.S. Geological Survey (USGS) began collecting data for an HGA of Graces Quarters in October 1986, at the request of the Environmental Management Office of APG, U.S. Department of Defense. The purpose of the HGA was to provide a framework to characterize any release and movement of contaminants in the vicinity of solid waste management units (SWMU's) and to provide information about chemical-agent test sites, including the type of chemical agent tested and the period in which testing took place.

Much of what is known about historical testing activities at Graces Quarters is described in the RCRA Facility Assessment for the Edgewood Area (Nemeth, 1989), and in Tenbus and Phillips (1990). Hydrogeologic data from the HGA can be found in Ham and others (1991). Interpretations of the hydrogeology and water quality of Graces Quarters from data collected during the HGA can be found in Tenbus and Blomquist (1995).

In February 1990, the Edgewood Area of APG was placed on the USEPA National Priority List. Since that time, the Edgewood Area studies have been under the guidelines of CERCLA (Comprehensive Environmental Response, Compensation, and Liability Act). The data and reports from the HGA were used to help plan the Remedial Investigation/Feasibility Study (RI/FS) at Graces Quarters.

The RI/FS at Graces Quarters is designed to verify and characterize environmental contamination at the study sites, to assess the associated potential risks to human health and welfare and to the environment, and to propose and describe alternative remedial actions that will mitigate confirmed environmental contamination at each site where remediation is deemed necessary (Dames \& Moore, Inc., 1993, p. 1-5). This work, which is ongoing as of 1996, includes four rounds of ground-water sampling, two rounds of surfacewater sampling, and one round of soil and sediment sampling, along with well installation and hydrogeologic interpretation. Results from the first two rounds of ground-water sampling (Dames \& Moore, Inc., 1995a, p. 5-227; 1995b, p. 4-63) and from previous USGS investigations (Tenbus and Blomquist, 1995, table 8) indicate that chlorinated volatile organic compounds (VOC's) are present in the ground water in concentrations exceeding $5,000 \mu \mathrm{g} / \mathrm{L}$ (micrograms per liter) in the eastcentral part of Graces Quarters.

\section{Purpose and Scope}

The purpose of this report is to describe ground-water flow and the results of the groundwater flow simulation of Graces Quarters, which was done by the USGS in conjunction with the RI/FS mandated by CERCLA for Graces Quarters. The report presents information on model construction and calibration, and on the simulations of various remedial-action scenarios for ground-water cleanup. 


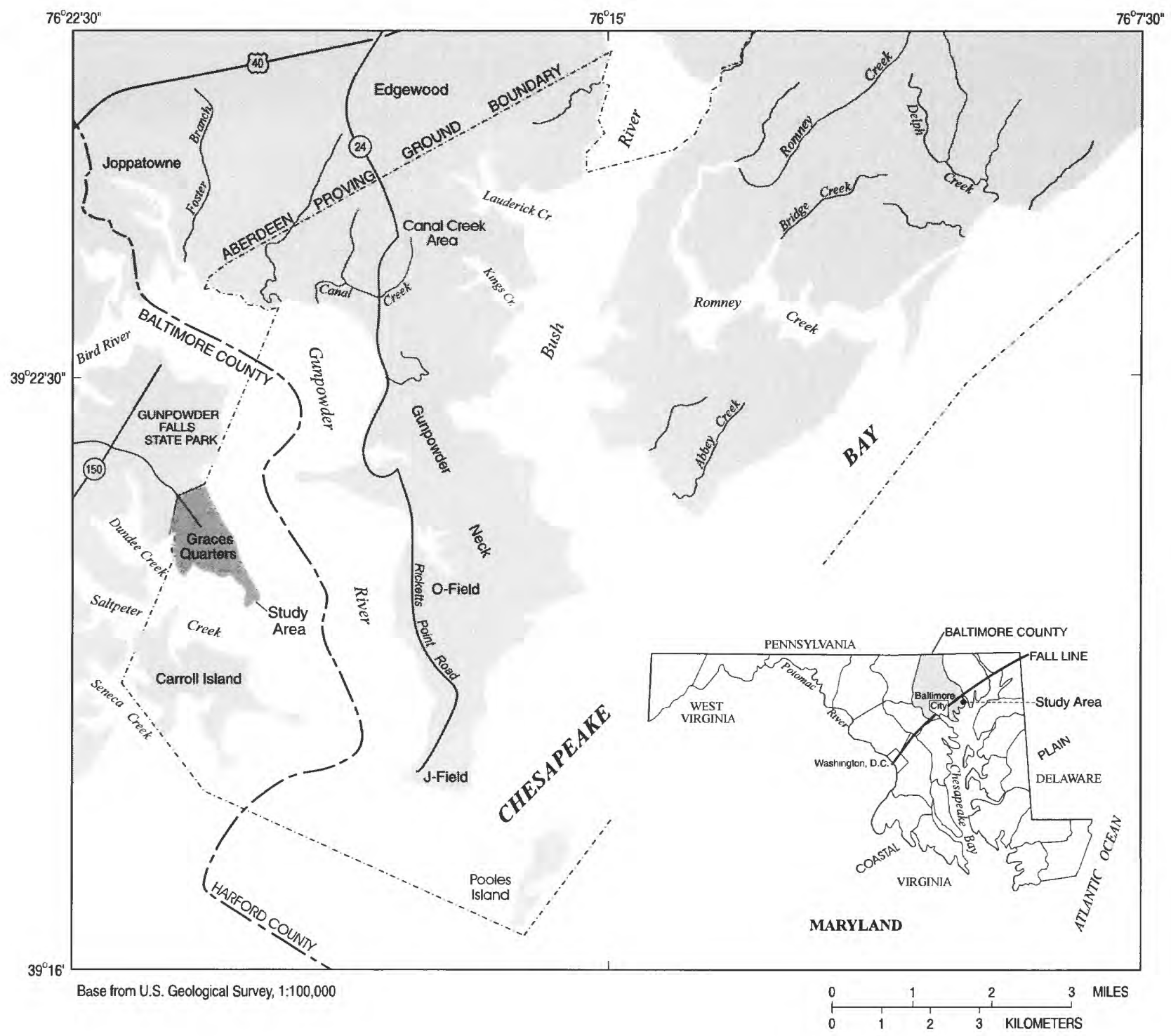

Figure 1. Location of Graces Quarters study area on Aberdeen Proving Ground near Baltimore, Maryland.

The objectives of the ground-water flow modeling were to (1) determine potential flow paths and conservative time of travel for ground water in known areas of contamination, and (2) simulate the effects of various ground-water remediation methods to help in the evaluation of potential clean-up scenarios. The hydrogeologic framework for the conceptual model of the ground-water flow system at
Graces Quarters was delineated on the basis of lithologic logs, well-construction data, aquifertest results, and various hydrogeologic interpretations published in reports from previous investigations. Ground-water flow was simulated using a quasi-three-dimensional finite-difference ground-water flow model. Flow paths were calculated with a particle-tracking subroutine of 
the model. The model was calibrated to water-level data collected in April and July 1994. The calibrated model was used to simulate potential changes in flow that would be caused by various ground-water remediation scenarios at Graces Quarters.

\section{Description of Study Area}

Aberdeen Proving Ground is located on the western shore of the Chesapeake Bay in Harford and Baltimore Counties, Maryland (fig. 1). The land area of APG covers about 30,000 acres (Nemeth, 1989, p. 1), and consists primarily of peninsulas and islands along the upper Chesapeake Bay. Graces Quarters is a 476-acre peninsula located in the southern part of the Edgewood Area of APG (fig. 1). The peninsula is surrounded on three sides by estuaries and is not connected by land to other parts of APG. The estuaries surrounding Graces Quarters include the Gunpowder River, Saltpeter Creek, and Dundee Creek. There are no perennial streams or rivers on Graces Quarters itself, but part of the land area is wetland (fig. 2).

\section{Regional Hydrogeology}

Graces Quarters is located within the Atlantic Coastal Plain Physiographic Province, which extends from Long Island, New York, to Texas (Fenneman, 1938). The Coastal Plain consists of unconsolidated deposits of sand, silt, and clay underlain by crystalline rock. This sediment begins at the Fall Line, which is the boundary between the Coastal Plain and the Piedmont Plateau, and thickens to the east in a wedge shape toward the Atlantic Ocean. The depth to bedrock in the Graces Quarters area is more than $300 \mathrm{ft}$ (Bennett and Meyer, 1952, pl. 5).

Graces Quarters is located on unconsolidated sediment that is mainly Cretaceous in age (Crowley and others, 1976) and classified as part of the Potomac Group (Otton and Mandle, 1984, p. 10). The Potomac Group, which consists of the Patuxent, Arundel, and Patapsco Formations, is of continental origin and most likely was deposited on the flood plains of rivers and in lakes and swamps (Vokes, 1957, p. 47-48). Delineation of the three formations within the Potomac Group can be difficult because sediment within each of the formations can be similar in appearance. Definition of the three formations at Graces Quarters is beyond the scope of this study; however, a general description of each is provided in the following paragraph.

The basal formation of the Potomac Group, called the Patuxent Formation, consists mainly of sand and gravel. The Patuxent Formation crops out in an area several miles west of Graces Quarters (Bennett and Meyer, 1952, pl. 2; Crowley and others, 1976). The top of the Patuxent Formation at Graces Quarters is more than $200 \mathrm{ft}$ below sea level (Chapelle, 1985, p. 7). The Arundel Formation overlies the Patuxent Formation and acts as a confining unit. The Arundel Formation is composed mainly of red and brown clay, but it also includes some layers and concretionary masses of sandstone cemented with iron oxide or iron carbonate (Vokes, 1957, p. 47). The Patapsco Formation, which consists of a sand facies and a clay facies, unconformably overlies the Arundel Formation (Bennett and Meyer, 1952, p. 59) and crops out on Graces Quarters (Bennett and Meyer, 1952, pl. 2; Crowley and others, 1976). All of the aquifers and confining units defined for this study (table 1) are considered part of the Patapsco Formation.

\section{Acknowledgments}

The authors wish to thank the following people for their contributions on various aspects of this study. Donald Green of the U.S. Army Directorate of Safety, Health, and Environment at APG and Patricia Franzen of Hazardous Waste Remedial Actions Program provided administrative assistance. Timothy Llewellyn and Scott Morgan of Dames \& Moore, Inc., and Alison Harlick and Steven Krispin of Hazardous Waste Remedial Actions Program provided technical assistance and some hydrogeological interpretations. 


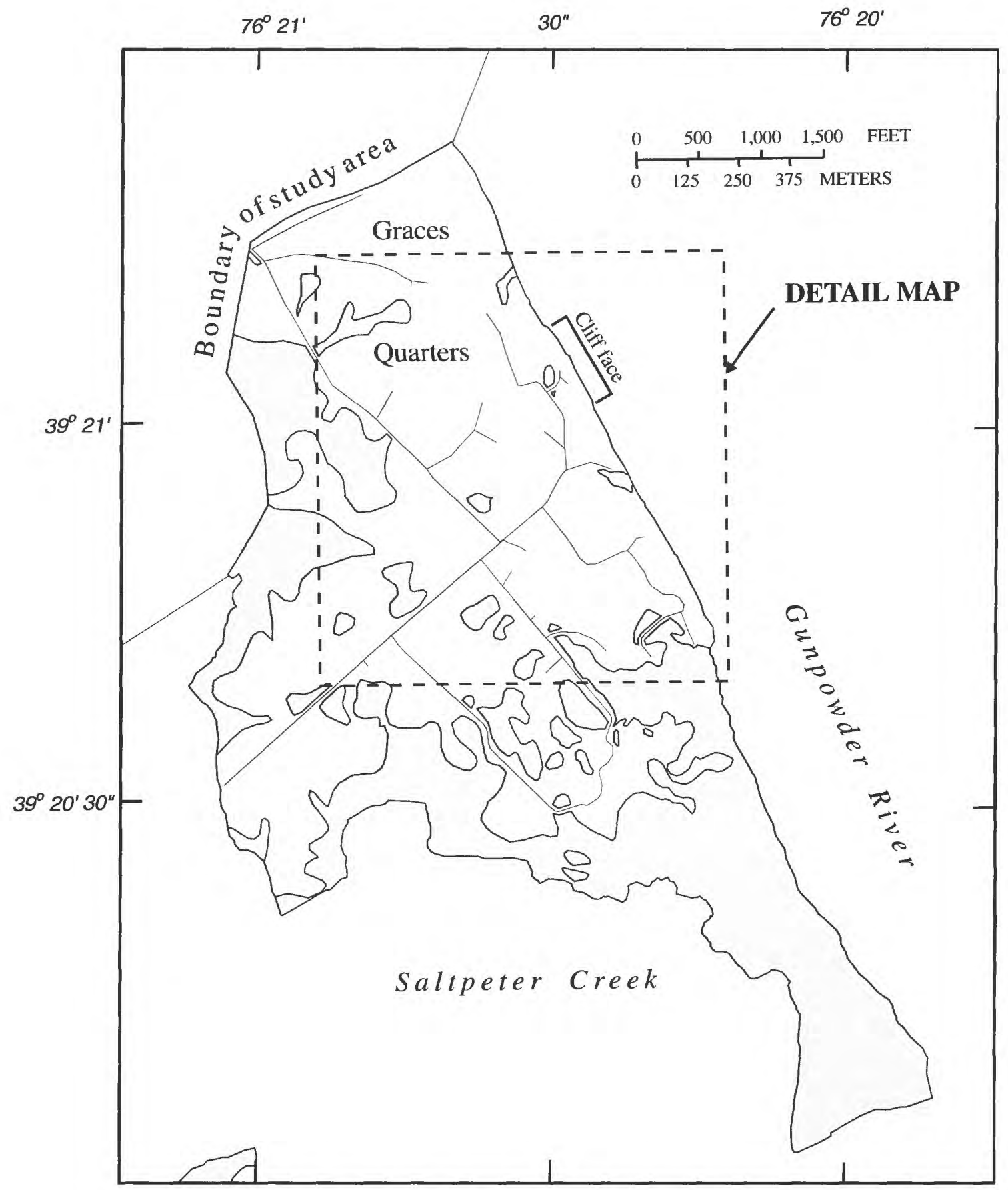

Base modified from U.S. Army, 1:4,800, 1970

\section{EXPLANATION}

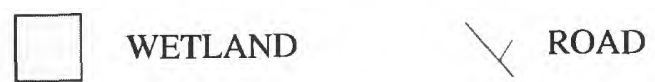

Figure 2. Location of roads and selected physiographic features at Graces Quarters, Aberdeen Proving Ground, Maryland. 


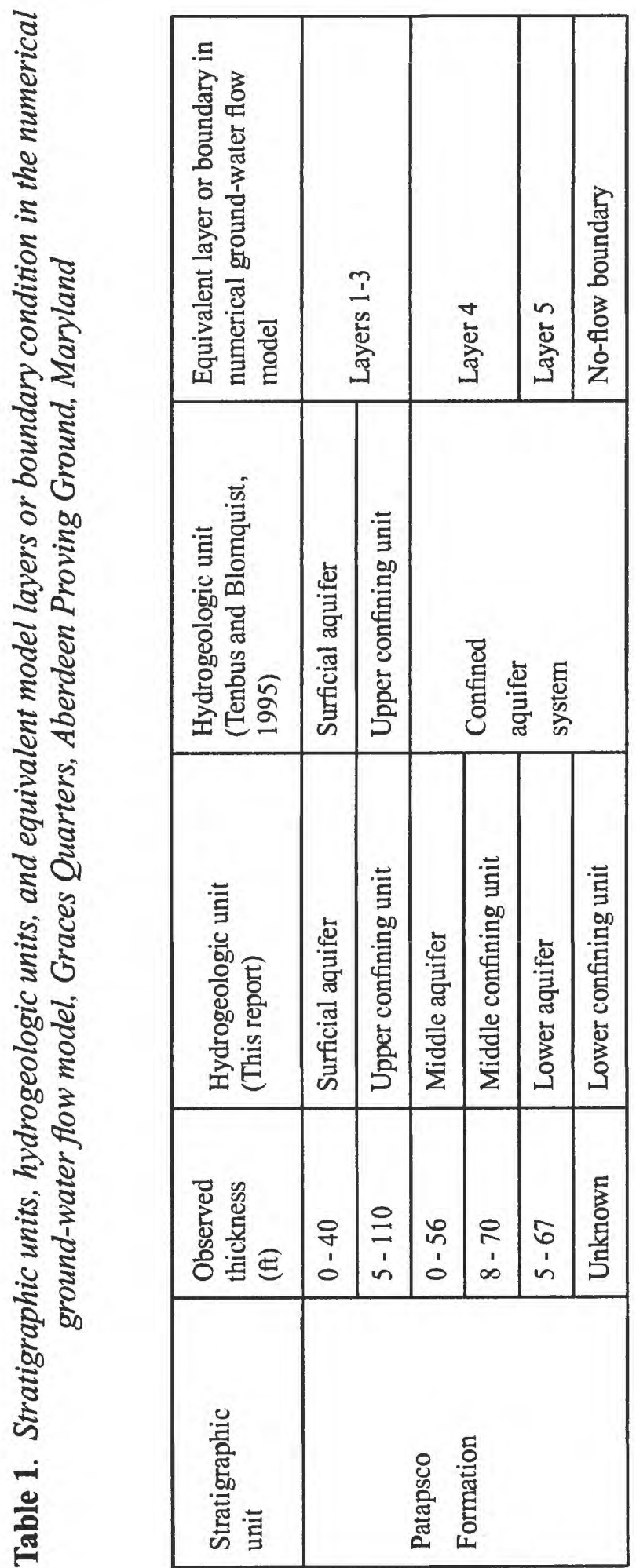




\section{GROUND-WATER FLOW}

Ground-water flow at Graces Quarters is difficult to characterize because of the complex nature of the sediment underlying the peninsula. Ground-water recharge comes from precipitation, but the recharge rate is influenced by the slope of the land surface, the presence of wetlands, and by the permeability of the surficial sediment. Groundwater discharge primarily is into the estuaries surrounding Graces Quarters, the wetlands adjacent to the estuaries, or both (Dames \& Moore, 1995a, p. 2-16).

During 1988-89, some confined-aquifer flow at Graces Quarters was toward a pumped well or wells at an unknown offsite location (Tenbus and Blomquist, 1995, p. 44-49). During the RI/FS, additional wells were drilled and completed in the confined aquifer system. Water-levels measured in 1994 for the RI/FS indicate that pumping at offsite wells affected hydraulic head in several of the new wells completed in the confined aquifer system; however, no effect was observed in the wells that were affected by pumping in 1988-89. In general, it appears that effects of pumping that have been observed at Graces Quarters are limited to poorly connected parts of the confined aquifer system and that overall, offsite pumping does not have much influence on ground-water flow at Graces Quarters.

\section{Aquifers and Confining Units}

The definitions of the individual aquifers and confining units that underlie Graces Quarters are somewhat arbitrary because the units are not necessarily continuous and the connections between them are only partly understood. There are no distinct lithologic differences to delineate one aquifer from another or one confining unit from another, and there is considerable spatial variation within each of the aquifers and confining units. Because of these conditions, all of the potential contaminant transport pathways between the various aquifers at the site have not been identified. However, the RI/FS process has been focused on areas where contaminant releases are known or suspected; therefore, the hydrogeology of the contaminated areas generally is well characterized. A schematic cross section of hydrogeologic units and generalized directions of ground-water flow at Graces Quarters is shown in figure 3.

Tenbus and Blomquist (1995, p. 25) identified the surficial aquifer, the upper confining unit, and the confined aquifer system at Graces Quarters (table 1). The same nomenclature also was used in Dames \& Moore, Inc. (1995a, p. 2-13), and a similar nomenclature is used in the current study. For this study, the surficial aquifer and upper confining unit identified in Tenbus and Blomquist (1995) and Dames \& Moore, Inc. (1995a) are the same, but the confined aquifer system is divided into a middle aquifer, middle confining unit, lower aquifer, and lower confining unit (table 1)

The surficial aquifer consists of sand and silt deposits that range in thickness (calculated from land surface to the top of the upper confining unit) from 0 to about $40 \mathrm{ft}$ (table 1 ). The aquifer is thickest in the southern and central parts of Graces Quarters (Dames \& Moore, Inc., 1995a, p. 2-13) and practically nonexistent in some of the northern and eastern parts of the peninsula. Horizontal hydraulic conductivity (as calculated from slug tests) in the surficial aquifer ranges from less than 0.01 to $24 \mathrm{ft} / \mathrm{d}$ (Tenbus and Blomquist, 1995, table $3)$.

Over most of the Graces Quarters area, the surficial aquifer is underlain by an upper confining unit, middle aquifer, middle confining unit, lower aquifer, and lower confining unit. Not all of these units are continuous. The upper confining unit, which is believed to be continuous over much of the Graces Quarters area, consists of silt, clay, and silty clay and ranges in thickness from 5 to $110 \mathrm{ft}$ (table 1). The middle aquifer, which consists of discontinuous sand deposits, ranges in thickness from 0 to $56 \mathrm{ft}$ (table 1). Horizontal hydraulic conductivity in the middle aquifer was calculated from slug tests in selected wells, and ranged from 1 to $68 \mathrm{ft} / \mathrm{d}$ (Tenbus and Blomquist, 1995, p. 49). The middle confining unit, which separates the middle aquifer (where it exists) from the lower aquifer, is 8 to $70 \mathrm{ft}$ thick (table 1) and consists of clay, silty clay, and possibly silt. In areas where the middle aquifer is nonexistent, the middle confining unit 


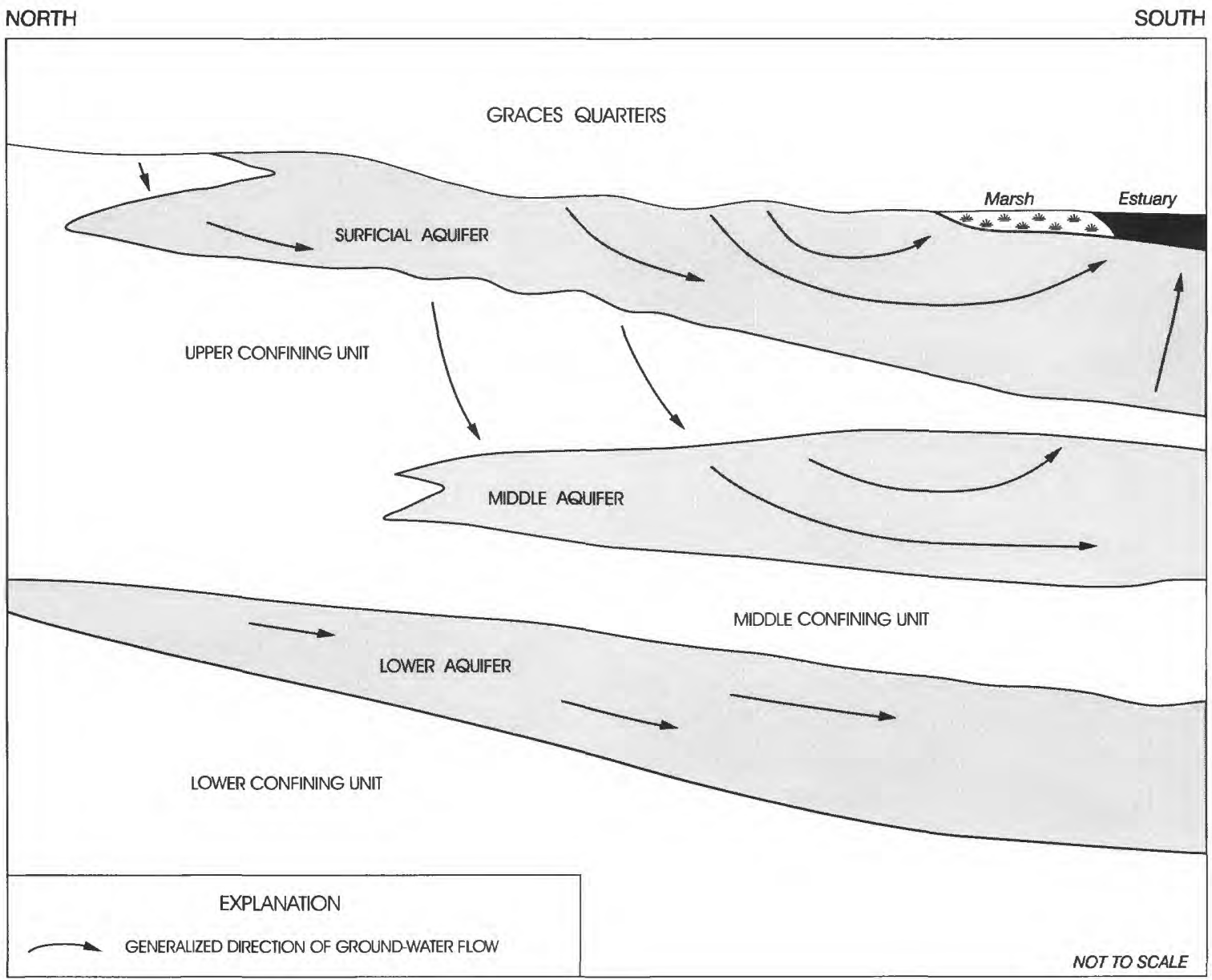

Figure 3. Hydrogeologic units and generalized ground-water flow directions at Graces Quarters, Aberdeen Proving Ground, Maryland.

is not differentiated from the upper confining unit. The lower aquifer, which consists of sand with some silt and clay, is 5 to $67 \mathrm{ft}$ thick where it has been encountered (table 1). The thickness and extent of the lower confining unit is not known.

Ground-water flow between aquifers and within the middle and lower aquifers is complex and incompletely understood. Tenbus and Blomquist (1995, p. 44-49) showed two distinct flow directions within the confined aquifer system, indicating that parts of the system are not hydraulically connected. Dames \& Moore, Inc. (1995a, p. 2-7 through 2-14; 1995b, p. 1-7) discuss the complexity of the system and express doubts that flow in the confined aquifers can be determined, even with the additional data collected in the RI/FS process.
In general, ground-water flow in the confined aquifer system in the northern part of Graces Quarters is controlled by thick clay deposits and discontinuous sand units, whereas ground-water flow in the confined aquifers in the southern part of the peninsula occurs in thicker, more continuous sand units. In the northern part of Graces Quarters, where the confining units are thick, ground-water flow between the aquifers is not likely to occur. Evidence for this can be found in Dames \& Moore, Inc. (1995b, fig. 1-5 and Appendix A) where hydraulic head is 0.27 to $0.45 \mathrm{ft}$ below sea level in some wells screened in the confined aquifers (indicating possible influence of offsite pumpage), and 1.51 to $1.79 \mathrm{ft}$ above sea level (indicating no pumpage influence) in nearby wells that also are screened 
in the confined aquifers. In the southern part of Graces Quarters, where confining-unit thickness is variable, flow between the aquifers may be significant. Evidence for this can be seen in hydrographs from wells screened in the middle aquifer at the southern part of Graces Quarters, where there is a pronounced seasonal variation in hydraulic head (Ham and others, 1991, figs. 17, 20, and 22), indicating seasonal recharge to the middle aquifer.

\section{Simulation of Flow}

The physical characteristics of the groundwater flow system at Graces Quarters were incorporated into a numerical flow model, which was calibrated to averaged hydraulic head conditions in April (a month representing high head conditions) and July (a month representing low head conditions) 1994. The model that was used to simulate these conditions was the USGS modular three-dimensional finite-difference ground-water flow model, commonly referred to as "MODFLOW" (McDonald and Harbaugh, 1988).

\section{Model Design and Boundary Conditions}

The model was used to simulate advective ground-water flow in a quasi three-dimensional mode, which means that the simulated flow is horizontal in the aquifers and vertical in the confining units. This mode, however, is not compatible with the conceptual model of groundwater flow at Graces Quarters, which includes a vertical component of flow in the surficial aquifer. Because of this, the surficial aquifer is divided into three layers, so that the simulated flow in the surficial aquifer could have a horizontal (within layers) and a vertical (between layers) component. The middle and lower aquifers are simulated as single layers, bringing the total number of model layers to five. The upper and middle confining units are simulated as leakances between layers. The lower confining unit is simulated as a no-flow boundary. The model assumes homogeneity and horizontal isotropy of aquifer properties within a given cell.

A grid (fig. 4) with a total area of $2.45 \mathrm{mi}^{2}$ was constructed to represent the Graces Quarters area in the model. The grid is oriented northwest to southeast to follow the orientation of the peninsula and the general stratigraphic dip in the area. The grid is divided into 79 rows and 56 columns for a total of 4,424 cells. Grid spacing is irregular, with cells ranging in width from $50 \mathrm{ft}$ in the east-central part of Graces Quarters to $600 \mathrm{ft}$ at the edge of the model. The width of each cell is no more than 1.5 times smaller or larger than that of any adjacent cell. This limit on grid expansion minimizes errors that occur when the finite-difference approximation of the governing equation for the model is used with an irregular grid spacing (Anderson and Woessner, 1992, p. 64).

The thickness of cells in the model can either be fixed or variable, depending on the relation between the top of the cell and the simulated water table. Thickness of cells in the layer that represents the water table is calculated by the model by subtracting the elevation of the bottom of the layer from the elevation of the water table that is calculated during each model iteration. Thickness of cells in the subsequent layers is not entered directly into the model, but is a factor in the transmissivity value for each cell. The thickness of confining units is a factor in the leakance values calculated between model layers.

Boundary conditions of the model were designed to reflect current understanding of the ground-water flow system in the Graces Quarters area. Various boundary conditions in the model include constant-head boundaries at the estuary edges and at the northwestern edge of the model area, river cells to represent wetlands, and a horizontal drain set at the edge of a cliff on the northeastern part of Graces Quarters (see fig. 2 for locations of wetlands and cliff). The upper boundary of the model is the water table, and the base of the model is a no-flow boundary representing the lower confining unit.

All boundaries were designed to be hydrogeologically accurate or have been placed at a far enough distance from the area of interest that they would have no significant effect on the accuracy of the model. The head in the estuary cells was held constant at about sea level to represent steady-state conditions. Because the northwestern edge of the modeled area is far from the area of primary interest and heads there may vary only 


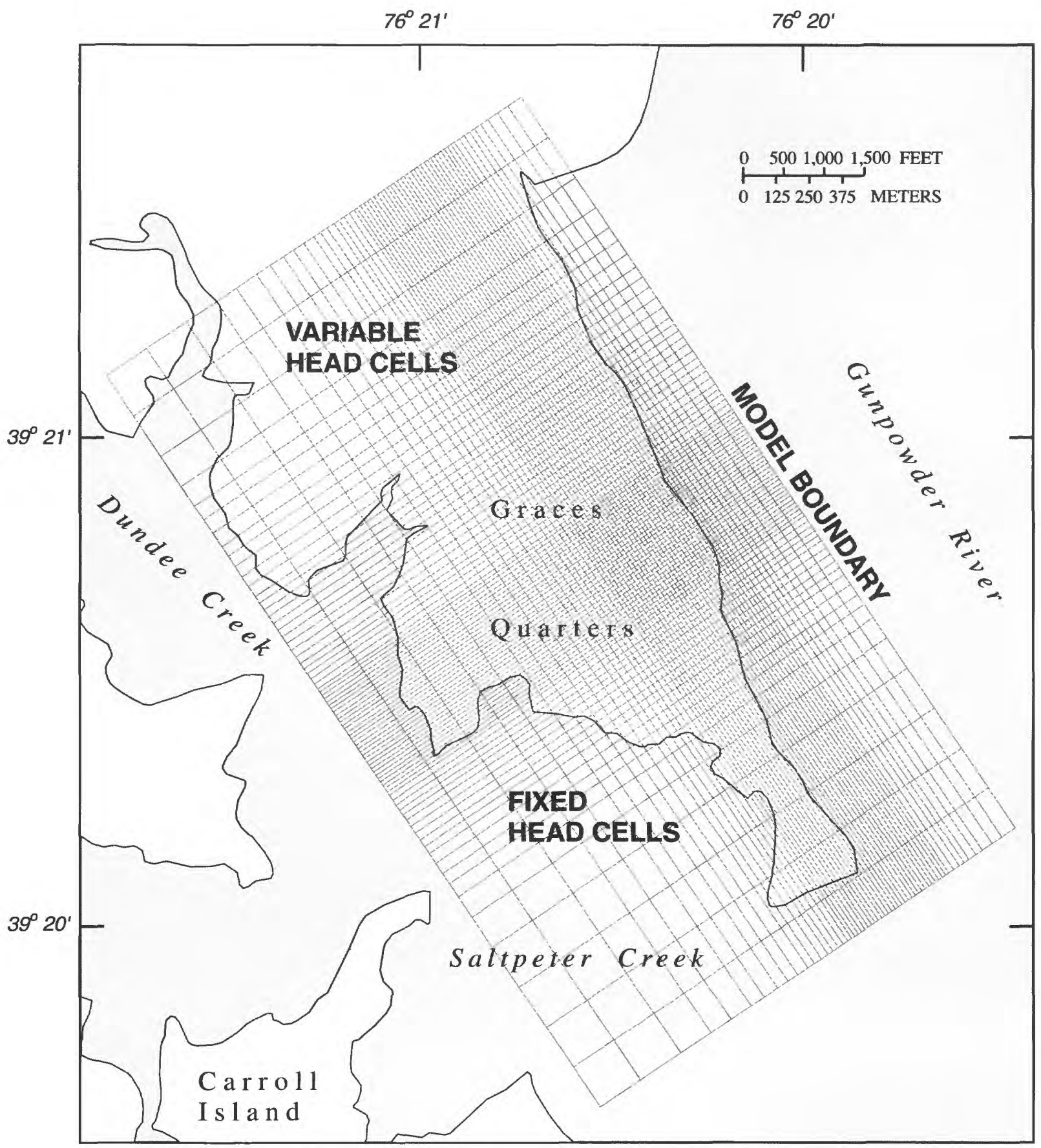

Base from U.S. Geological Survey, 1:24,000, 1986

Figure 4. Finite-difference grid and generalized lateral model boundaries. The shoreline was simulated as a boundary between fixed and variable head cells. 
slightly, that area was represented as a constanthead boundary. The wetlands (fig. 2) were represented in the model as river cells to allow flux to occur through the wetland sediments. The magnitude and direction of this flux depends on the specified leakance of the wetland sediments and the head gradient between the specified wetland or "river" head and the head in the aquifer at that cell. On the northeastern part of Graces Quarters, there is an area where the surficial aquifer crops out on a cliff face. Intermittent seepage has been noted along this cliff face (Tenbus and Blomquist, 1995, p. 36). This seepage was simulated in the model by a line of drain cells (set at the approximate elevation of the seepage face) next to a line of inactive cells, which enabled the seepage flux to occur when heads in the surficial aquifer were high enough.

Several zones representing areas of the surficial aquifer with different hydrogeological characteristics were included in the model. Zones of differing recharge (fig. 5) were based on topography, amount of clay in or above the surficial aquifer, and presence or absence of wetlands. The zones of simulated hydraulic conductivity are based on slug-test results, grain-size analysis, hydrograph analysis, and physical characteristics of the aquifers as described in the following section.

\section{Model Calibration}

The model was calibrated by systematically adjusting recharge and hydraulic conductivity within reasonable limits until the simulated head in the model layers acceptably matched the averaged observed head. Synoptic water-level measurements were made in April and July 1994 (Dames \& Moore, Inc., 1995b, p. 1-3). April is a time of high head conditions because it is a period of low evapotranspiration (ET) and high recharge. In contrast, July is a period of high ET and low recharge and thus is a time of low head. Therefore, an average of the measured head for the two synoptic periods is a good estimate of average conditions to be simulated by the steady-state ground-water flow model.

Water-level measurements from 33 observation wells in the surficial aquifer (fig. 6) were used for calibration of simulated water levels. In the calibrated model, the mean difference between the simulated and averaged measured head was about $1 \mathrm{ft}$. A match was considered acceptable if the simulated and averaged measured heads agreed within about $2.7 \mathrm{ft}$, because a difference of $2.7 \mathrm{ft}$ is 10 percent of the total range $(27.3 \mathrm{ft})$ of averaged measured head within the model area. This is consistent with the calibration criterion of the ground-water flow model for O-Field, APG (Vroblesky and others, 1995, p. 76), where a 0.5-ft difference ( 10 percent of the total range of $5 \mathrm{ft}$ ) between the simulated head and the average observed head was used to determine a match. An acceptable match was obtained at all but four comparison points (fig. 7).

For the confined aquifers, measurements from 6 wells (April and July 1994) and 11 wells (July 1994) were available for calibration (5 wells in the confined aquifers were installed after the April 1994 synoptic measurements). Less emphasis was placed on calibration in the layers representing the confined aquifers because there is no known contamination in the confined aquifers, the confined flow system is not well defined, and there were fewer wells and water-level measurements in the confined aquifers to calibrate against. In the calibrated model, the mean difference between simulated head and averaged measured head in the middle and lower aquifers was $2.0 \mathrm{ft}$.

Model inputs that were adjusted to attain calibration included recharge and hydraulic conductivity. Recharge was varied areally because of the heterogeneous nature of the physical features of Graces Quarters. Soil type, topography, and location in the flow regime were some of the factors used to determine recharge zones. Ultimately, however, the recharge rates applied to the zones were adjusted somewhat arbitrarily so that a satisfactory calibration could be obtained. Anderson and Woessner (1992, p. 153) indicate that there often is little hydrogeologic information to use when defining recharge zones and assigning recharge rates to them, and that recharge zonation usually is justified on the basis of a successful calibration. 


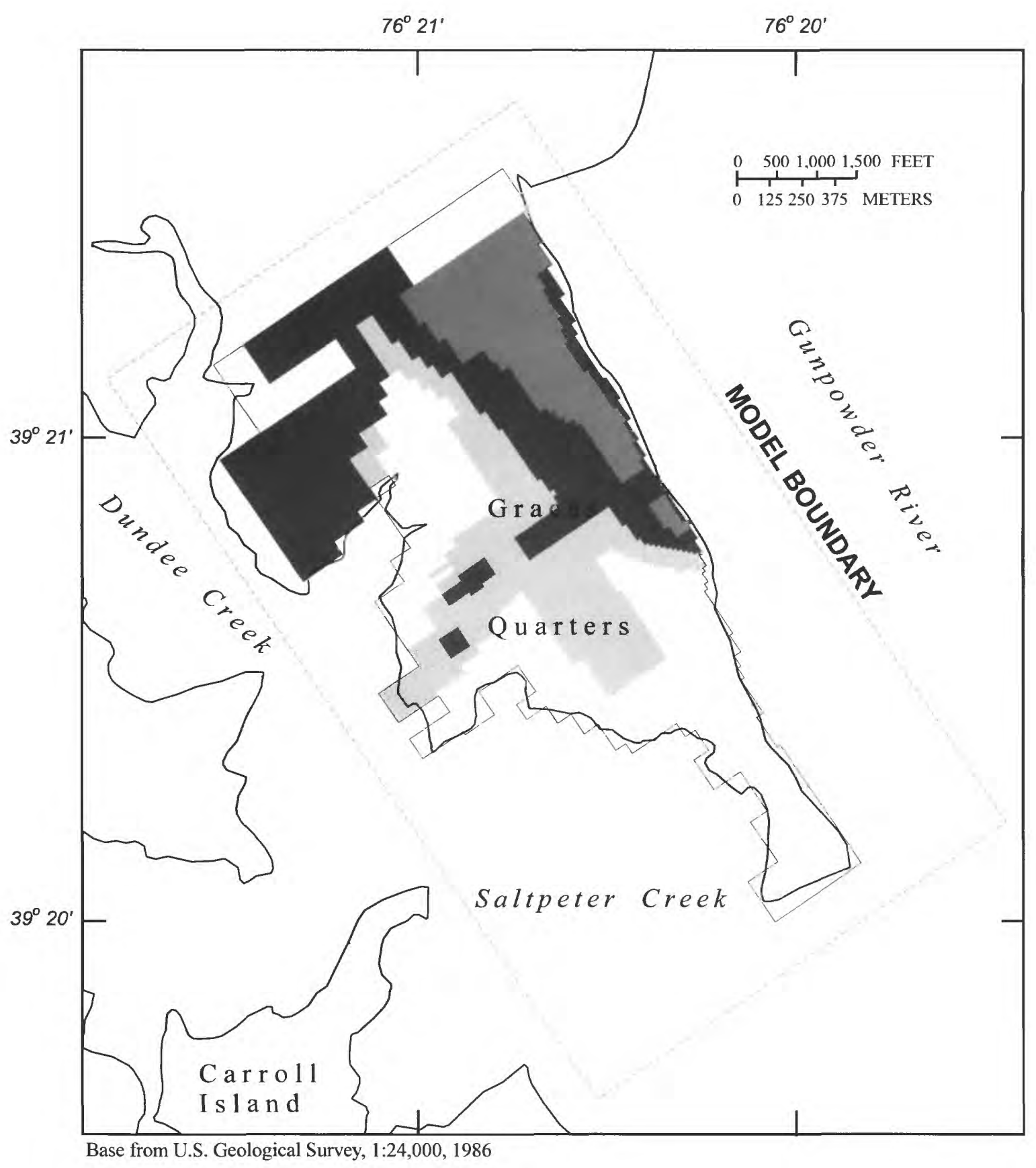

EXPLANATION

RECHARGE RATE APPLIED TO MODEL AREA, IN INCHES PER YEAR

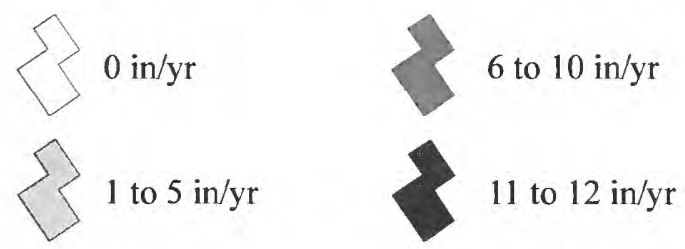

Figure 5. Zones of simulated recharge for the ground-water flow model. 


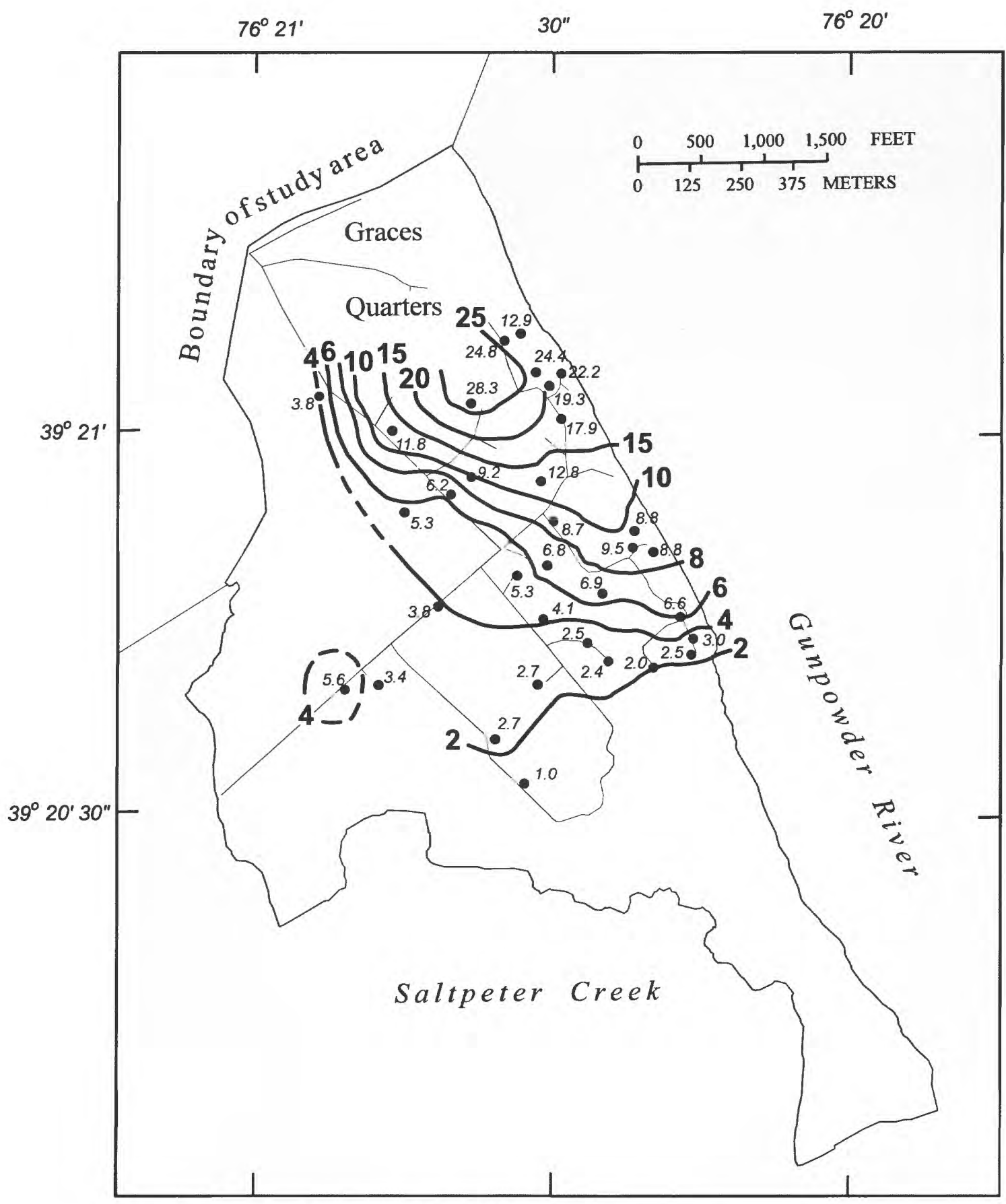

Base modified from U.S. Army, 1:4,800, 1970

\section{EXPLANATION}

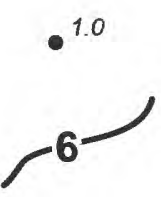

OBSERVATION WELL -- Number

is water level, in feet. Datum is sea level.

LINE OF EQUAL HYDRAULIC HEAD --

Interval variable, in feet.

Dashed where approximately located.

Datum is sea level.

Figure 6. Averaged hydraulic head in the surficial aquifer, Graces Quarters, Aberdeen Proving Ground, Maryland, April and July 1994. 


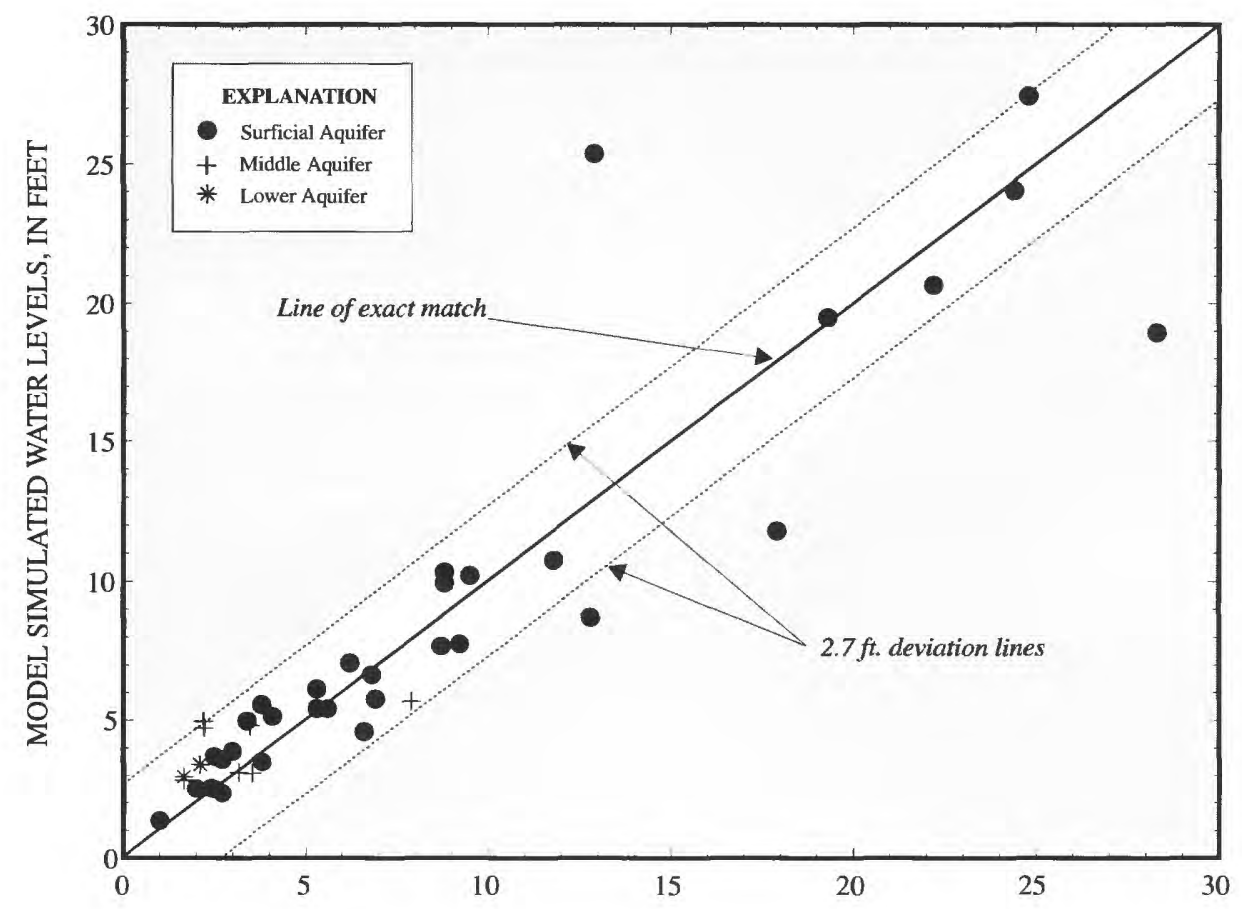

AVERAGED MEASURED WATER LEVELS IN FEET, APRIL AND JULY, 1994 (Datum is sea level).

Figure 7. Relation between measured and simulated water levels at Graces Quarters, Aberdeen Proving Ground, Maryland.

Total recharge for the calibrated model was $42,000 \mathrm{ft}^{3} / \mathrm{d}$, which is equivalent to about $6.5 \mathrm{in} / \mathrm{yr}$ over the modeled area. This recharge was distributed areally with a range of 0 to $12 \mathrm{in} / \mathrm{yr}$. In the topographically high areas of Graces Quarters where ground-water levels are highest (fig. 6), the land surface is underlain by extensive silty and clayey soils. The model was calibrated with an input of 6 in/yr of recharge to the larger of these areas, and 10 in/yr to the smaller (fig. 5). It is believed that much of the precipitation that falls on these areas does not infiltrate to the water table there, but runs off to lower areas or is evaporated or transpired. Overland flow from the topographic high areas of Graces Quarters was noted by Tenbus and Blomquist (1995, p. 19).
In the area adjacent to the topographic highs, a recharge rate of 11 to $12 \mathrm{in} / \mathrm{yr}$ was applied (fig. 5). This rate is similar to that used by Vroblesky and others $(1995$, p. 76$)$. Near the wetlands, a recharge rate of 1 to $5 \mathrm{in} / \mathrm{yr}$ (determined through calibration) was applied. No recharge was applied in the model to the wetland areas and some of the areas immediately adjacent to the wetlands. This is justified in a steady-state model even if there are times within the year where recharge occurs in the wetlands, because on average more ground water is being removed from the system in these areas than is being recharged. Evidence of this includes an evapotranspiration rate that is high enough to draw water levels in observation wells near the wetlands to below sea level during dry seasons 
(Dames \& Moore, Inc., 1995b, fig. 1-4; Tenbus and Blomquist, 1995, fig. 16), and an upward hydraulic gradient in the surficial aquifer near the wetland during a wet season (Tenbus and Blomquist, 1995, p. 37).

Hydraulic conductivity was varied areally according to results obtained from slug tests (Tenbus and Blomquist, 1995, table 3), from analysis of well response to tides, and from analysis of grain-size distribution. Hydraulic conductivity in the surficial aquifer over most of the modeled area ranged from 0.001 to $50 \mathrm{ft} / \mathrm{d}$. Known variations in hydraulic conductivity at Graces Quarters were taken into account during model calibration. Table 2 indicates that horizontal hydraulic conductivity in the surficial aquifer at Grace Quarters varies over three orders of magnitude. The values listed from the slug-test analyses (Tenbus and Blomquist, 1995, table 3) range from less than 0.02 to $24 \mathrm{ft} / \mathrm{d}$. Hydraulic conductivity calculated from sieve analyses (Ham and others, 1991, table 7) by the Hazen (1911) method (Fetter, 1994, p. 99) ranges from 0.04 to $17 \mathrm{ft} / \mathrm{d}$. The range of values calculated by each method is similar; individual values (table 2 ) also are similar.

In addition to the values obtained from slug tests and grain-size determination, horizontal hydraulic conductivity was determined from the response of well hydrographs to tidal fluctuations in the nearby estuaries. Well and estuary hydrographs for these determinations were generated from unpublished data collected from a tide gage on the Gunpowder River near Graces Quarters and from automatic water-level recorders on selected wells. These data are on file in the Towson, Md., USGS District Office.
Table 2. Summary of hydraulic conductivity values used to calibrate the groundwater flow model at Graces Quarters, Aberdeen Proving Ground, Maryland

[For well locations, see Tenbus and Blomquist (1995, fig. 3) or Dames \& Moore. Inc. (1995a, fig. 3-1). --, value not calculated: <, less than]

\begin{tabular}{|c|c|c|c|c|}
\hline \multicolumn{5}{|c|}{ Hydraulic conductivity values (feet per day), calculated from: } \\
\hline & $\begin{array}{l}\text { Slug } \\
\text { tests } 1\end{array}$ & & $\begin{array}{l}\text { Grain-size } \\
\text { determinations }\end{array}$ & $\begin{array}{l}\text { Tidal } \\
\text { responses }{ }^{3}\end{array}$ \\
\hline $\begin{array}{l}\text { Well } \\
\text { no. }\end{array}$ & $\begin{array}{l}\text { Cooper } \\
\text { method }^{4}\end{array}$ & $\begin{array}{l}\text { Hvorslev } \\
\text { method }^{5}\end{array}$ & $\begin{array}{l}\text { Hazen } \\
\text { method }^{6}\end{array}$ & $\begin{array}{l}\text { Ferris } \\
\text { method }^{7}\end{array}$ \\
\hline
\end{tabular}

\begin{tabular}{llllr}
\multicolumn{5}{l}{ WELLS SCREENED IN THE SURFICIAL AQUIFER } \\
Q07 & -- & $<0.1$ & -- & -- \\
Q08 & -- & -- & 0.04 & -- \\
Q10 & -- & .5 & -- & -- \\
Q11 & -- & -- & -- & 11 \\
Q12 & $<0.01$ & $<.1$ & -- & 7 \\
Q13 & -- & 13 & -- & \\
Q14 & 22 & 7 & 17 & -- \\
Q15 & 6 & 7 & 4 & - \\
Q16B & -- & -- & -- & - \\
Q17 & -- & -- & 14 & - \\
& & & & - \\
Q18A & 24 & 8 & 4 & - \\
Q26 & $<.02$ & $<.1$ & .9 & - \\
Q27 & -- & -- & .07 & - \\
Q28 & $<.02$ & $<.1$ & .9 & -
\end{tabular}

WELLS SCREENED IN THE MIDDLE OR LOWER AQUIFER

$\begin{array}{lrrcc}\text { Q09B } & - & -- & .03 & 3 \\ \text { Q16A } & 1 & -- & 4 & 31 \\ \text { Q18B } & 34 & -- & 15 & 23 \\ \text { Q19 } & -- & -- & .4 & 13 \\ \text { Q20A } & 68 & -- & -- & 40\end{array}$

${ }^{1}$ Values from Tenbus and Blomquist (1995, table 3 and p. 49)

${ }^{2}$ Data presented in Ham and others (1991, table 7)

${ }^{3}$ From unpublished data on file at the Towson, Md., USGS District Office

${ }^{4}$ Cooper and others (1967)

${ }^{5}$ Hvorslev (1951)

${ }^{6}$ Hazen (1911)

${ }^{7}$ Ferris (1963) 
The first step in determining hydraulic conductivity values from tidal fluctuations was to calculate diffusivity (transmissivity divided by storage coefficient). Two methods were used (Ferris, 1963, p. 306-309). The first method calculates diffusivity from amplitude differences between the fluctuations in the estuary and the well with the following equation, rearranged from Todd (1980, p. 244):

$$
\mathrm{D}=\frac{\mathrm{x}^{2} \pi}{\mathrm{t}_{\mathrm{o}}\left[\ln \left(\frac{\mathrm{h}_{\mathrm{x}}}{\mathrm{h}_{\mathrm{o}}}\right)\right]^{2}}
$$

where

$\mathrm{x}$ is the distance from the shore to the observation well (L),

$\mathrm{t}_{0}$ is the time between high or low tide changes (T),

$h_{0}$ is half the amplitude between high and low tides (L),

$h_{x}$ is half the amplitude as recorded at the observation well (L), and

$\mathrm{D}$ is the diffusivity $\left(\mathrm{L}^{2} \mathrm{~T}^{-1}\right)$.

The second method calculates diffusivity from the time lag between fluctuations in the estuary and the well with the equation (Fetter, 1994, p. 377):

$$
D=\frac{t_{0}}{4 \pi\left(\frac{t_{\tau}}{x}\right)^{2}}
$$

where

$t_{\tau}$ is lag time between high or low tide in the estuary and the corresponding high or low at the observation well (T).

Many calculations for the eight hydrographs that showed tidal fluctuations were made for each of the parameters listed above. Diffusivity was then calculated by cach method and an average was obtained.
Hydraulic conductivity was then calculated from the calculated diffusivities. For confined conditions (Freeze and Cherry, 1979, p. 61),

$$
\mathrm{D}=\frac{\mathrm{K}}{\mathrm{S}_{\mathrm{s}}}
$$

where

$\mathrm{K}$ is hydraulic conductivity $\left(\mathrm{LT}^{-1}\right)$,

$\mathrm{S}_{\mathrm{s}}$ is specific storage $\left(\mathrm{L}^{-1}\right)$,

and (Fetter, 1994, p. 116)

$$
S_{s}=\rho_{w} g(\alpha+n \beta)
$$

where

$\rho_{\mathrm{w}}$ is the density of water $\left(998 \mathrm{~kg} / \mathrm{m}^{3}\right)$, $\mathrm{g}$ is the acceleration duc to gravity $\left(9.8 \mathrm{~m} / \mathrm{s}^{2}\right)$, $\alpha$ is the coefficient of vertical compressibility of the aquifer matrix (in units of $\mathrm{m}^{2} / \mathrm{N}$ ),

$\mathrm{n}$ is the porosity of the aquifer material (dimensionless), and

$\beta$ is the compressibility of water $\left(4.6 \times 10^{-10}\right.$ $\left.\mathrm{m}^{2} / \mathrm{N}\right)$.

Because the value of $n \beta$ is very small compared to $\alpha$, the value used for porosity is not important. Thus, the only variable of concern in the equation is the coefficient of vertical compressibility of the aquifer matrix. Vertical compressibility is a function of the aquifer material (Domenico and Schwartz, 1990, table 4.1; Freeze and Cherry, 1979, table 2.5). Similarly, hydraulic conductivity is a function of the aquifer material (Domenico and Schwartz, 1990, table 3.2; Fetter, 1994, table 4.6). For average values from the tables in the texts cited above, the empirical relation between diffusivity and hydraulic conductivity is

$$
\log (K)=0.76 \log (D)-3.38
$$


where

$\mathrm{K}$ is hydraulic conductivity ( $\mathrm{ft} / \mathrm{d}$ ), and $\mathrm{D}$ is diffusivity $\left(\mathrm{ft}^{2} / \mathrm{d}\right)$.

Thus, from the calculated diffusivities, an estimate of hydraulic conductivity can be obtained. These hydraulic conductivity values (table 2 ) range over one order of magnitude, which contrasts with the three orders of magnitude range from the slug tests and grain-size determinations. This is probably reasonable, because the damping of tidal fluctuations observed in a well results from aquifer characteristics over a large aquifer volume, whereas the slug tests and grain-size determinations sample only a small part of the aquifer.

Following the initial calibration of the flow model, lithologic descriptions from 44 Geoprobe $^{1}$ sites located in the east-central part of Graces Quarters were obtained (Scott Morgan, Dames \& Moore, Inc., written commun., 1995). These data were collected during spring and summer, 1995. The Geoprobe results provided sufficient data to justify redescribing the surficial aquifer, subdividing it into three layers (which enabled better particle-tracking definition), and recalibrating the model. The aquifer was subdivided into three layers by vertically dividing the thickness of the aquifer into three equal parts for each model cell. The model code required that each of the three layers of the aquifer be separated by a confining unit. This was done by specifying a confining unit with a thickness of $1 \mathrm{ft}$ and an initial hydraulic conductivity of $1 \mathrm{ft} / \mathrm{d}$.

The lithology of the sediment encountered by the Geoprobe was described by letter symbols from the Unified Soil Classification System (Casagrande, 1948). A hydraulic conductivity value was assigned to each of these letter symbols (table 3) (Domenico and Schwartz, 1990, table 3.2; Fetter, 1994, table 4.6; Freeze and Cherry, 1979, table 2.2), and an average hydraulic conductivity was calculated for each of the three model layers representing the surficial aquifer at each of the 44 Geoprobe locations. This average hydraulic conductivity was then assigned to the appropriate model cell, and a weighted average hydraulic conductivity was assigned to model cells with no Geoprobe data.

The equation to calculate an average hydraulic conductivity (Lee and Fetter, 1994, p. 128-129) is

$$
\mathrm{K}_{\mathrm{xy}}=\frac{\Sigma \mathrm{K}_{\mathrm{i}} \mathrm{d}_{\mathrm{i}}}{\mathrm{d}}
$$

where

$\mathrm{K}_{\mathrm{xy}}$ is horizontal hydraulic conductivity $\left(\mathrm{LT}^{-1}\right)$,

$\mathrm{K}_{\mathrm{i}}$ is the horizontal hydraulic conductivity as described for the $i^{\text {th }}$ vertical increment for the given layer $\left(\mathrm{LT}^{-1}\right)$,

$d_{i}$ is the vertical length of the $i^{\text {th }}$ increment $(L)$, and

$d$ is the total length of all $i$ increments (L).

The vertical hydraulic conductivity for the $1-\mathrm{ft}$ confining unit was then modified to reflect the variation in horizontal hydraulic conductivity. To obtain representative values for the clay and silt stringers within the aquifer, vertical hydraulic conductivity for the $1-\mathrm{ft}$ confining units was calculated from one-third of the layer thickness above to one-third of this distance below the confining unit. The equation to calculate the effective vertical hydraulic conductivity is (Lee and Fetter, 1994, p. 127-128)

$$
\mathrm{K}_{\mathrm{z}}=\frac{\mathrm{d}}{\Sigma\left(\frac{\mathrm{d}_{\mathrm{i}}}{\mathrm{K}_{\mathrm{i}}}\right)}
$$

where

\footnotetext{
1 Any use of trade. product, or firm names is for descriptive purposes only and does not imply endorsement by the U.S. Government.
} 
Table 3. Hydraulic conductivity values used in ground-water flow model for indicated letter symbol from Unified Soil Classification System

[Letter symbols and typical descriptions for the Unified Soil Classification System (Casagrande, 1948) obtained from Dames \& Moore, Inc. (1995c. Appendix B)]

\begin{tabular}{|c|c|c|}
\hline $\begin{array}{l}\text { Letter } \\
\text { symbol }\end{array}$ & $\begin{array}{l}\text { Typical } \\
\text { description }\end{array}$ & $\begin{array}{l}\text { Modeled } \\
\text { hydraulic } \\
\text { conductlvity } \\
\text { values } \\
\text { (feet per day) }\end{array}$ \\
\hline SW & $\begin{array}{l}\text { Well-graded sand, gravelly } \\
\text { sand, little or no fines }\end{array}$ & 50 \\
\hline SP & $\begin{array}{l}\text { Poorly-graded sand, gravelly } \\
\text { sand, little or no fines }\end{array}$ & 10 \\
\hline SM & Silty sand, sand-silt mixtures & 1 \\
\hline SC & Clayey sand, sand-clay mixtures & .1 \\
\hline ML & $\begin{array}{l}\text { Inorganic silt and very fine sand. } \\
\text { rock flour, silty or clayey fine } \\
\text { sand, or clayey silt with slight } \\
\text { plasticity }\end{array}$ & .01 \\
\hline $\mathrm{CL}$ & $\begin{array}{l}\text { Inorganic clay of low to medium } \\
\text { plasticity, gravelly clay, sandy } \\
\text { clay, silty clay, lean clay }\end{array}$ & .00005 \\
\hline OL & $\begin{array}{l}\text { Organic silt and organic silty clay } \\
\text { of low plasticity }\end{array}$ & .001 \\
\hline $\mathrm{MH}$ & $\begin{array}{l}\text { Inorganic silt, micaceous or } \\
\text { diatomaceous fine sand or } \\
\text { or silty soil }\end{array}$ & .05 \\
\hline $\mathrm{CH}$ & $\begin{array}{l}\text { Inorganic clay of high plasticity, } \\
\text { fat clay }\end{array}$ & .00005 \\
\hline $\mathrm{OH}$ & $\begin{array}{l}\text { Organic clay of medium to high } \\
\text { plasticity, organic silt }\end{array}$ & .0005 \\
\hline
\end{tabular}

and the other variables are the same as equation (6). The leakance for each confining unit in the flow model is the effective vertical hydraulic conductivity divided by the thickness of the unit for each model cell. Because the assigned thickness for the two confining units within the surficial aquifer is $1 \mathrm{ft}$, leakance in these confining units is equal to the effective vertical hydraulic conductivity.
The result of these calculations was an array of hydraulic conductivity values to be used as model input. This array represented an estimate of the hydraulic conductivity at several scales within the aquifers at Graces Quarters. Final calibration, however, required that the areally extensive hydraulic conductivity values be adjusted within reasonable limits so that an appropriate head match could be obtained.

\section{Sensitivity Analysis}

Prior to final calibration of the model, sensitivity analyses were performed to evaluate the effects of changes in horizontal hydraulic conductivity of the surficial aquifer, recharge to layer 1 , leakance between the surficial and confined aquifer system, and transmissivity of the confined aquifer system. Preliminary analysis provided an indication of the inputs to which the model was sensitive. Each of these four input parameters were globally varied from one-tenth to ten times the bestmatch value of the mean deviation. The simulated heads were compared to the averaged measured heads used in the calibration process, as described earlier. Results of the analyses (fig. 8) indicate the global sensitivity of these four inputs. The sensitivity analysis also provided a tool to help understand the effects of these inputs over a more localized area.

The results of the analyses (fig. 8) indicate that the simulated heads are most sensitive to increases in the horizontal hydraulic conductivity of the surficial aquifer, increases in recharge to layer 1, and decreases in leakances between the surficial aquifer and the confined aquifer system. In contrast, decreases in hydraulic conductivity of the surficial aquifer and increases in leakance had minimal effect on the simulated hydraulic head. Additionally, changes in the transmissivity of the middle and lower aquifers had very little effect on simulated hydraulic head in the surficial aquifer. 

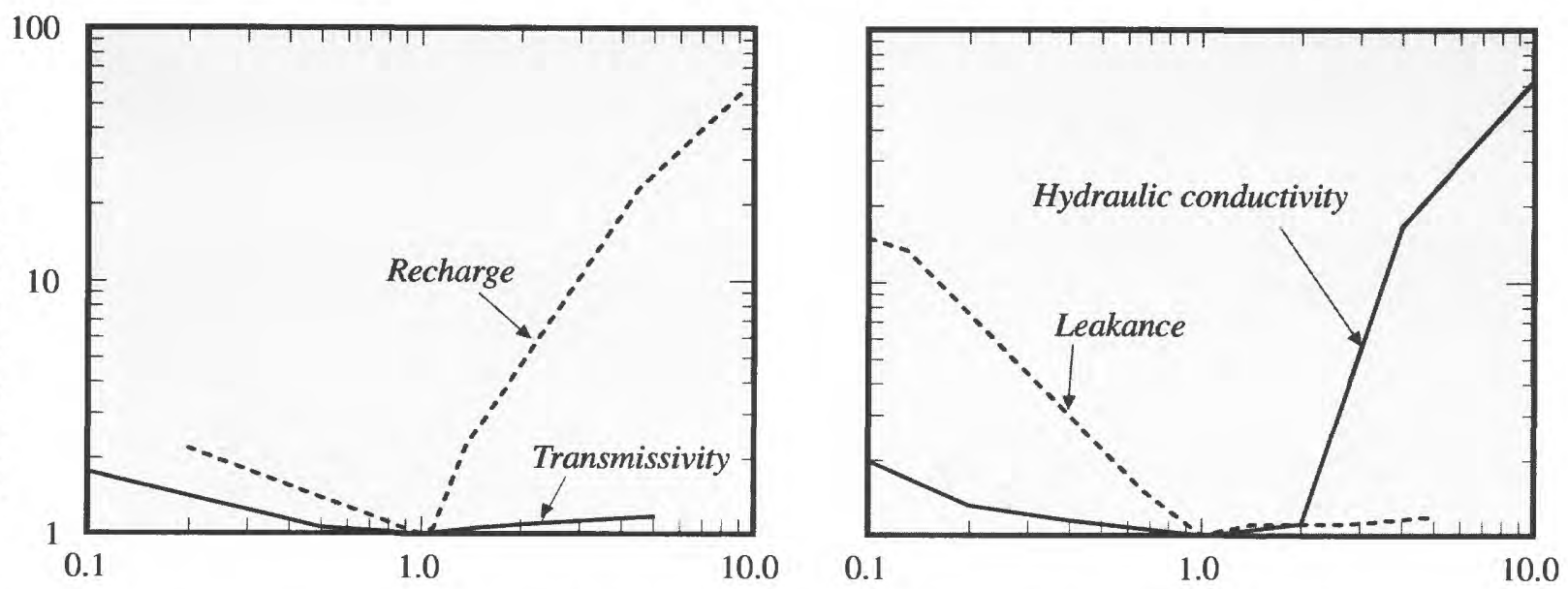

FACTOR USED TO MULTIPLY BEST FIT VALUE OF GIVEN INPUT PARAMETER

Figure 8. Sensitivity of simulated hydraulic head to changes in recharge, transmissivity, leakance, and hydraulic conductivity.

\section{POTENTIAL EFFECTS OF REMEDIA- TION}

Several remedial actions were simulated by using the calibrated ground-water flow model for the Graces Quarters area. These remedial actions included a no-action scenario (for comparison purposes) and three pumpage scenarios with one to three pumped wells in various locations within the surficial aquifer in the east-central part of Graces Quarters. The objective of these simulations was to examine ground-water flow and conservative transport of contaminants in the various scenarios to help with decisions regarding the optimum remedial action for ground water in the surficial aquifer.

Ground-water flow paths were simulated using the calibrated model and a particle-tracker subroutine developed by Pollock (1989). Particle tracking can be used as a simple means to evaluate the advective flow of ground-water systems, but cannot be used to calculate solute concentrations because it does not account for dispersion or adsorption (Hughes, 1995, p. 24). Traveltime for water particles also can be approximated with the particle tracker.
Hughes (1995, p. 24-25) describes some of the assumptions inherent in the use of the particle-tracker subroutine to assess contaminant transport:

The particle-tracker subroutine does not track the paths of chemical contaminants in ground water. These chemicals are subject to a variety of physical processes such as dispersion and adsorption, as well as chemical reactions that can alter their composition and transport characteristics. In general, these processes tend to slow down the movement of contaminants relative to ground water, and as a result, calculated travel times for ground water are likely to be shorter than the actual travel times of chemical contaminants. The particletracker subroutine can provide an indication . of the general direction and relative rates of advective chemical transport within a ground-water flow system and can be useful when selecting potential remediation techniques for a specific site. 


\section{No-Action Scenario}

A no-action scenario was simulated to compare flow directions and traveltimes during unstressed conditions with those during times of pumpage. Ground-water flow during unstressed conditions has been described in Tenbus and Blomquist (1995, p. 33-37) and in Dames \& Moore, Inc. (1995a, b). In general, unstressed groundwater flow in most parts of the surficial aquifer at Graces Quarters (except for the areas within a few hundred feet of the Gunpowder River on the eastern shore of the peninsula) is to the south or southwest (Dames \& Moore, Inc., 1995b, figs. 1-3 and 1-4).

The ground-water flow model shows a flow direction that is similar to that determined from field measurements, which is to be expected because it was calibrated to values that were representative of these measurements. Figure 9 shows contours of simulated head in the surficial aquifer from the calibrated model, as well as the results of a particle-tracking simulation showing groundwater flow directions from the area where high concentrations of chlorinated VOC's were detected. For all particle tracking simulations, the porosity values used were 30,35 , and 40 percent for the confined aquifers, water-table aquifer, and confining units, respectively. These values were calculated from sieve analyses (Ham and others, 1991, table 7) used in conjunction with a soil-classification triangle (Johnson, 1967, fig. 1). Figure 10 shows a time series of the same particle-tracking simulation in cross section. In the simulation, the particles were placed near the center of mass of the current (1994) chlorinated VOC plume and allowed to track forward for 200 years at steady state.

Figure 9 shows ground-water flow paths in the surficial aquifer from the central parts of the chlorinated VOC plume to the discharge area in the wetland. In this simulation, it was shown that under unstressed conditions, ground water from the contaminated area would reach its discharge point, a non-tidal wetland, within 5 to 10 years.
Figure 10 indicates that during the same 5- to 10 -yr timeframe, ground water from areas contaminated with chlorinated VOC's would reach the middle aquifer. Ground-water flow in the middle aquifer is to the south, and it appears to be somewhat slower than flow in the surficial aquifer (fig. 10). The model results indicate that it would take 100 to 200 years for ground water that has flowed into the middle aquifer to discharge back at the surface (fig. 10). The model also indicates that ground water from the contaminated part of the surficial aquifer would not reach the lower aquifer within the $200-\mathrm{yr}$ simulation period.

The downward movement of ground-water particles in this simulation is supported by hydraulic head data collected by USGS in 1988-89 on Graces Quarters (Ham and others, 1991). These data indicate that the hydraulic gradient between the surficial and middle aquifers is consistently downward (Ham and others, 1991, table 8, p. 3638 ) and that hydraulic head in the middle aquifer is affected by seasonal variations in recharge (Ham and others, 1991, figs. 17, 20, and 22). The presence of a downward hydraulic gradient indicates the potential for downward ground-water flow; the seasonal hydraulic head variations in the middle aquifer indicates that there is a hydraulic connection between the surficial and middle aquifers. Therefore, the flow paths indicated by this simulation are plausible.

The limitations of this particle-tracking simulation are (1) it assumes that the model is calibrated correctly and that it accurately represents the hydrologic system; (2) it assumes that contaminant movement is conservative; that is, there is no retardation of contaminants, no dispersion or diffusion, and no density difference between the contaminants and ground water; and (3) it assumes that hydrologic conditions will remain the same at Graces Quarters for the next 200 years. It is important to consider these limitations when using this model and particle-tracking subroutine for predictive purposes at Graces Quarters. 


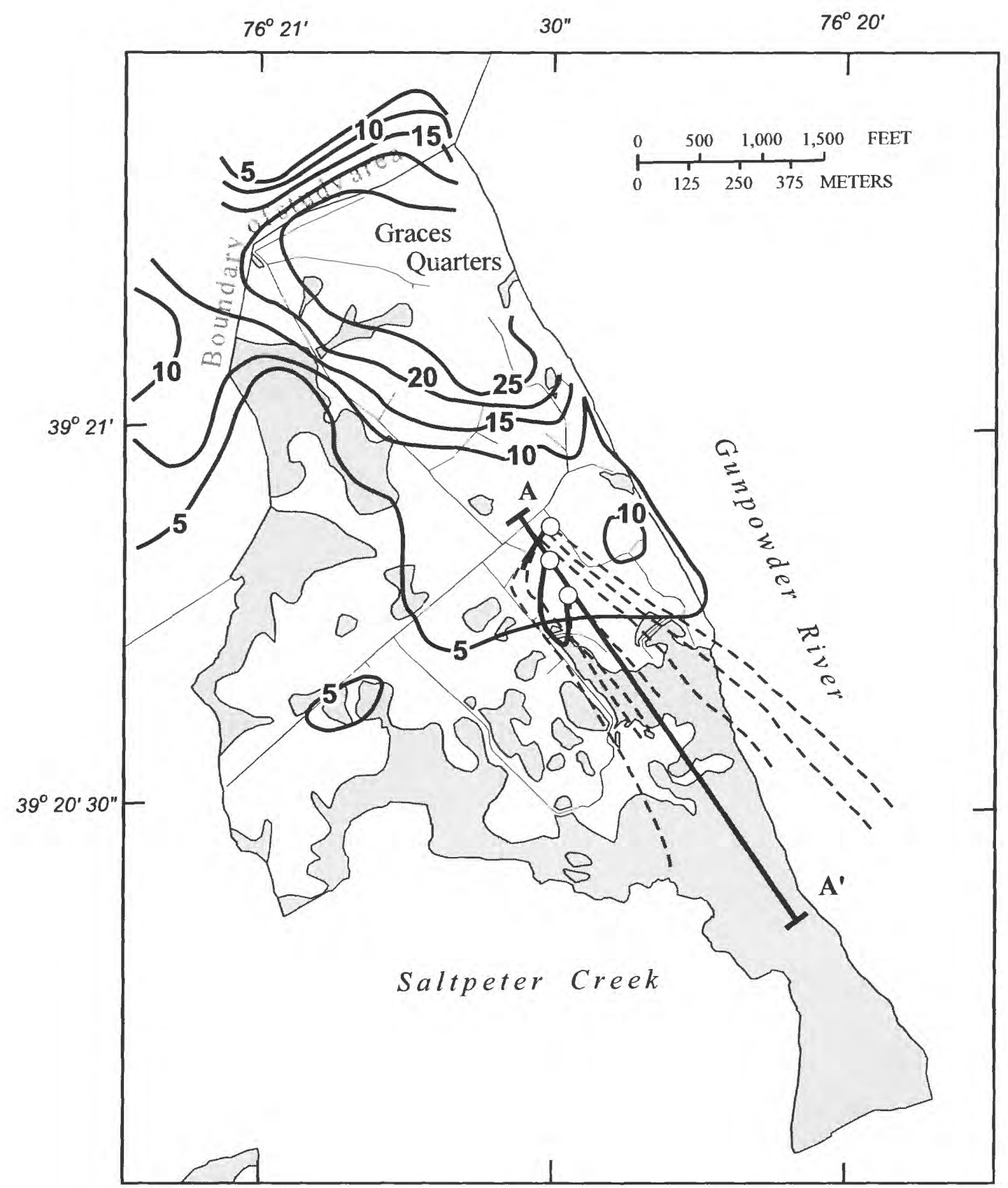

Base modified from U.S. Army, 1:4,800, 1970

\section{EXPLANATION}

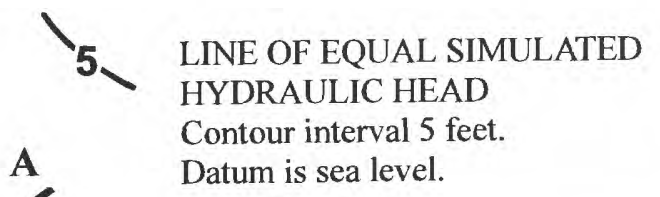

SIMULATED GROUND-WATER PATHLINES

Starting Location

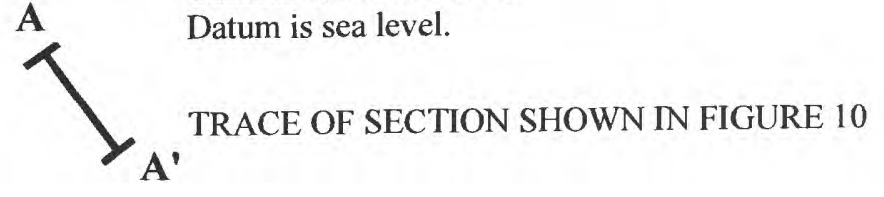

Water-table aquifer

isiddle confined aquifer

Figure 9. Simulated hydraulic head in the surficial aquifer and ground-water pathways for conservative transport from contaminated areas under the no-action scenario. 


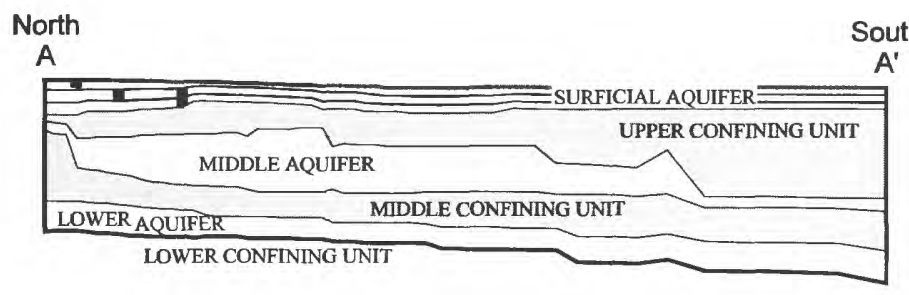

Initial location of plume

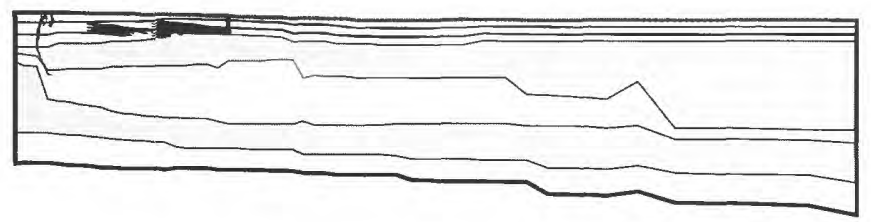

After 5 Years

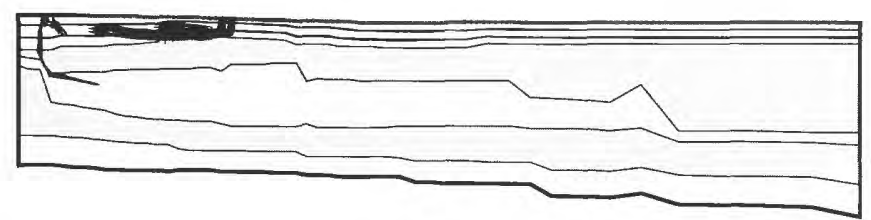

After 10 Years

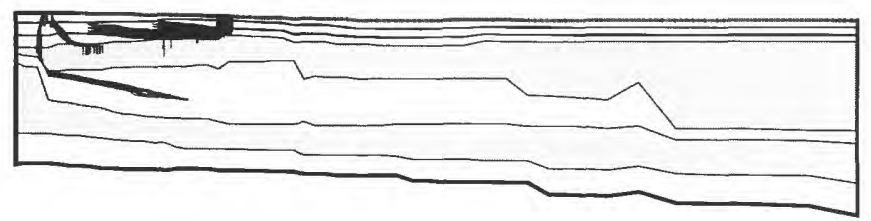

After 25 Years

\section{EXPLANATION}

SIMULATED AQUIFER LAYER

$\square$ SIMULATED CONFINING UNIT

mim SIMULATED GROUND-WATER PATHLINE

After 50 Years

After 100 Years
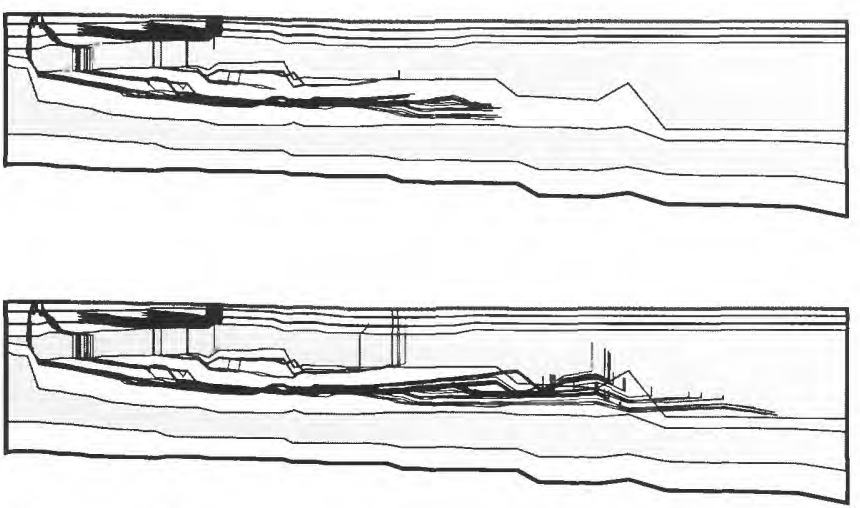

After 200 Years

0100,700 FEET

Vertical Exaggeration is 5.0

Figure 10. Model layers and simulated ground-water pathways for 5, 10, 25, 50, 100, and 200 years of conservative transport from contaminated areas under the no-action scenario. Line of section shown in figure 9. 


\section{Pumpage Scenarios}

Three pumpage scenarios were suggested as being helpful for evaluating some of the potential remediation efforts at Graces Quarters (Scott Morgan, Dames \& Moore, Inc., written commun., 1995). These scenarios are (1) a single well pumped at $7 \mathrm{gal} / \mathrm{min}$; (2) three wells, each pumped at $7 \mathrm{gal} / \mathrm{min}$, with the wells lined up in an approx- imate north-south direction; and (3) three wells, each pumped at $7 \mathrm{gal} / \mathrm{min}$, lined up in a southwestnortheast direction, with recharge of $7 \mathrm{gal} / \mathrm{min}$ injected into the well for scenario 1 (fig. 11). In each of these scenarios, the wells are screened in the lower part of the surficial aquifer to intercept contamination by chlorinated VOC's that may be denser than water and therefore transported

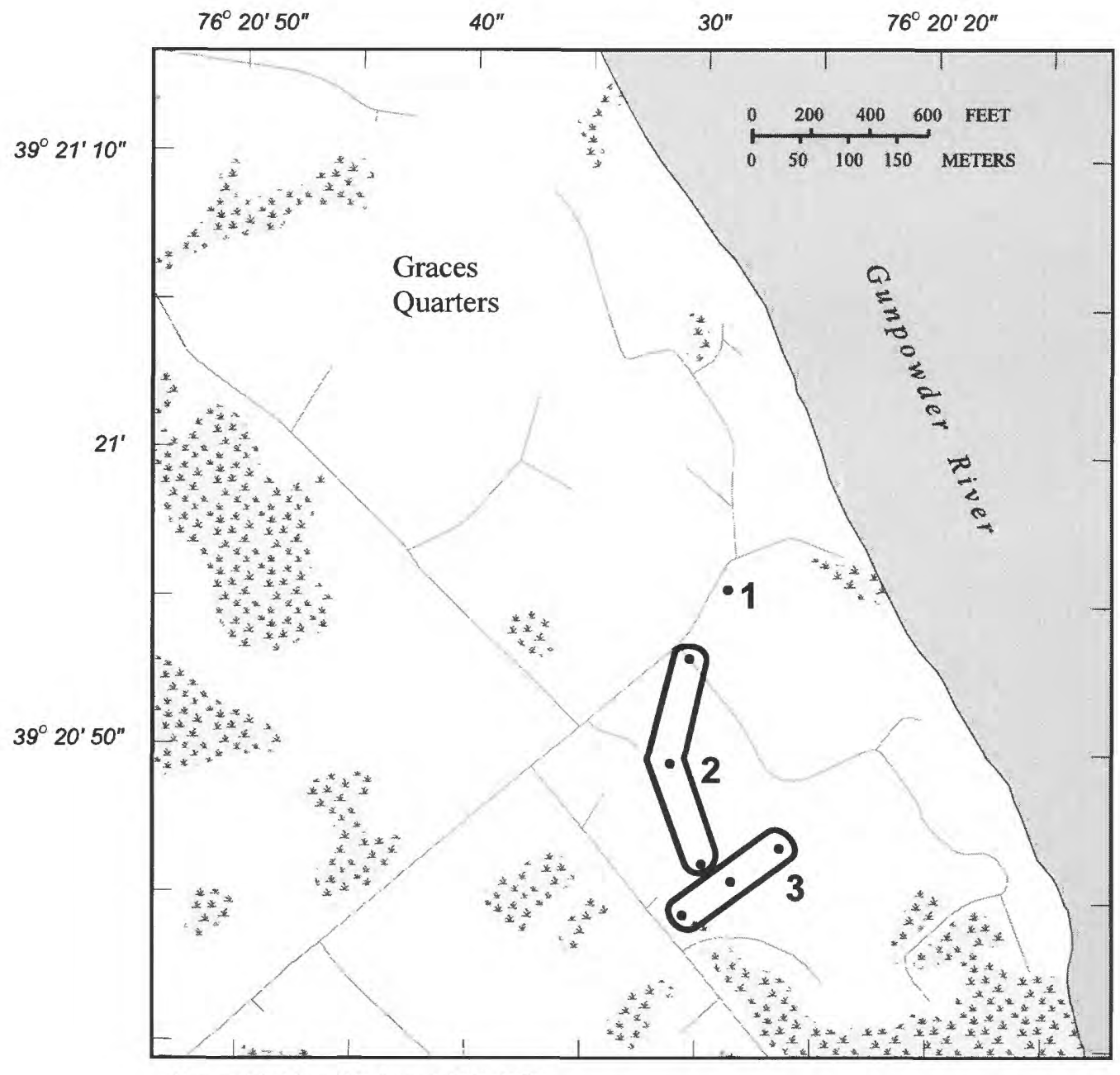

Base modified from U.S. Army, 1:4,800, 1970

EXPLANATION

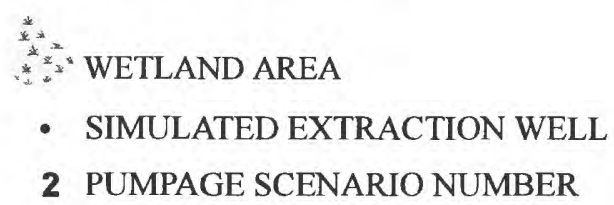

Figure 11. Location of simulated extraction wells for pumpage scenarios 1 to 3 . 
along the surface of the upper confining unit. The $7 \mathrm{gal} / \mathrm{min}$ pumping rate was chosen because this rate was sustained in a well located in the same general area as the pumpage scenarios during a 72-hr pumping test conducted in summer 1995 (Scott Morgan, oral commun., 1995). Pathlines from backward tracking analysis defined capture zones shown in figs. 12-14. In scenario 2 and 3 , the capture zone includes only the water-table aquifer. In scenario 1 , about 2 percent of the water particles, as represented by the pathlines, move down through the upper confining unit into the middle aquifer.

\section{Scenario 1}

Scenario 1 consists of pumping one simulated extraction well at $7 \mathrm{gal} / \mathrm{min}$ near what is believed to be either the source or one of several sources of the highest concentrations of chlorinated VOC's detected in the ground water at Graces Quarters. The location of the extraction well (fig. 11) is upgradient of the highest detected concentrations of chlorinated VOC's (Scott Morgan, written commun., 1995). In this area, the top of the upper confining unit is relatively shallow (approximately at sea level) and slopes to the south (Dames \& Moore, Inc., 1995a, fig. 2-4). The purpose of this remediation scheme would be to reverse the hydraulic gradient and draw contaminants back toward their source for removal and treatment.
Such a remediation scheme is not likely to be successful (fig. 12). The central part of the chlorinated VOC contaminant plume is located approximately where the extraction wells for scenario 2 are located (fig. 11). The capture zone (fig. 12) for the extraction well does not overlap all of these locations, which indicates that the objective of the remedial action would not be met.

\section{Scenario 2}

Scenario 2 consists of pumping $7 \mathrm{gal} / \mathrm{min}$ from each of three simulated extraction wells that are oriented in a north-south direction (fig. 11) along the axis of the highest detected concentrations of chlorinated VOC's (Scott Morgan, written commun., 1995). The purpose of this scenario is to determine the capture zone for an extraction well field if the wells were placed at or near the center of greatest mass of contaminants. This remediation scheme would attempt to remove contaminants from the concentrated areas and reverse the hydraulic gradient to prevent further transport toward the wetlands and estuaries. 


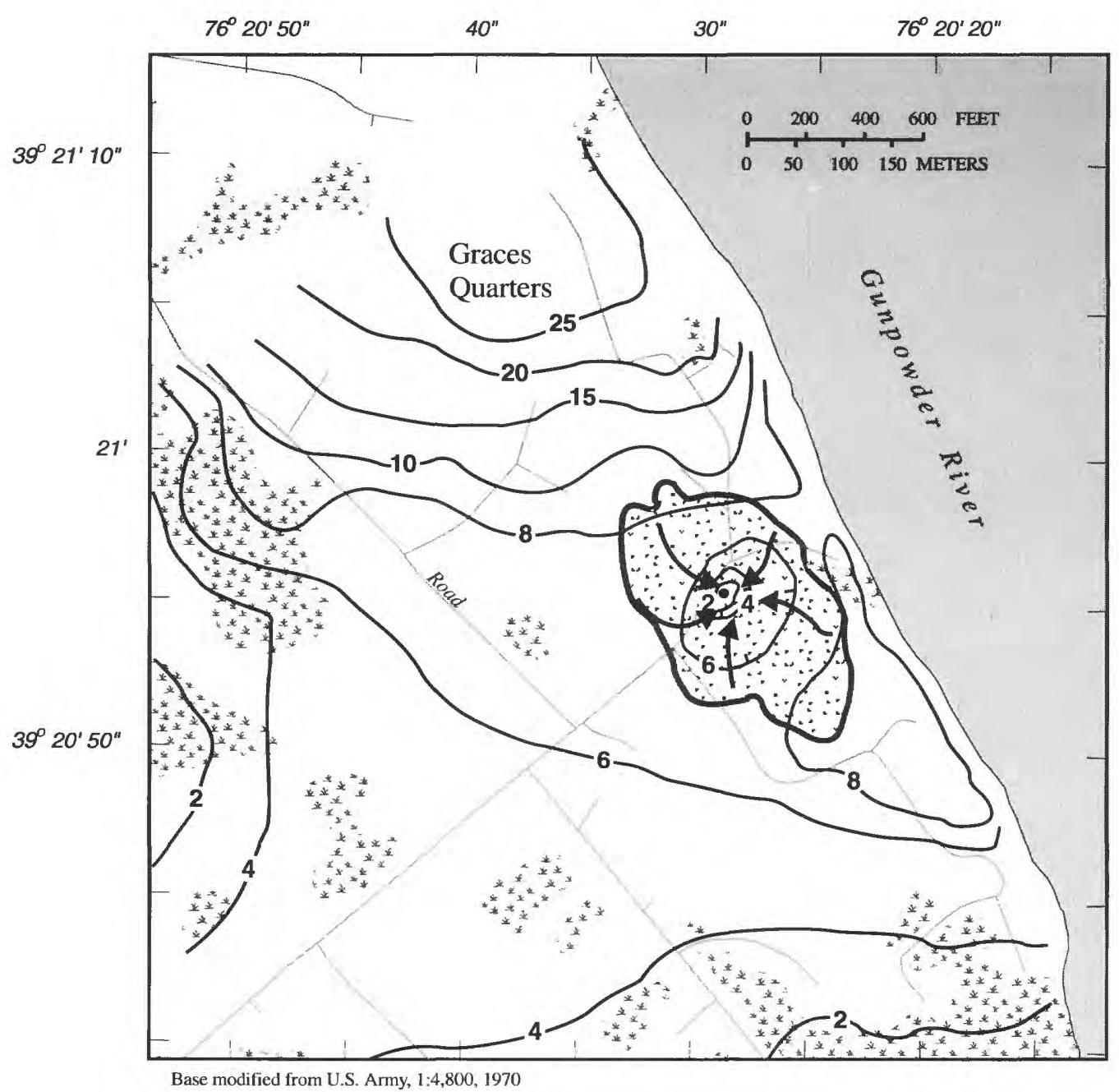

EXPLANATION

WETLAND AREA

6INE OF EQUAL SIMULATED HYDRAULIC HEAD

2. CAPTURE ZONE

- PUMPED WELL

Figure 12. Location of simulated extraction well, hydraulic head in the surficial aquifer, and ground-water pathlines for pumpage scenario 1.

The pumpage from scenario 2 may or may not have adverse effects on the natural hydrologic system at Graces Quarters. Simulated water levels (fig. 13) indicate that there would be a net discharge of ground water into the wetland that is located in the southern part of the figure, just as there was during unstressed conditions. However, the pumpage scenario is designed to remove $21 \mathrm{gal} / \mathrm{min}$ from the ground-water flow system ( 3 extraction wells pumped at $7 \mathrm{gal} / \mathrm{min}$ each). This would be a reduction of recharge to the system of about $4,000 \mathrm{ft}^{3} / \mathrm{d}$, which is almost 10 percent of the $42,000 \mathrm{ft}^{3} / \mathrm{d}$ applied to the calibrated model. Removal of this much water from the system may reduce ground-water discharge to the wetlands. 


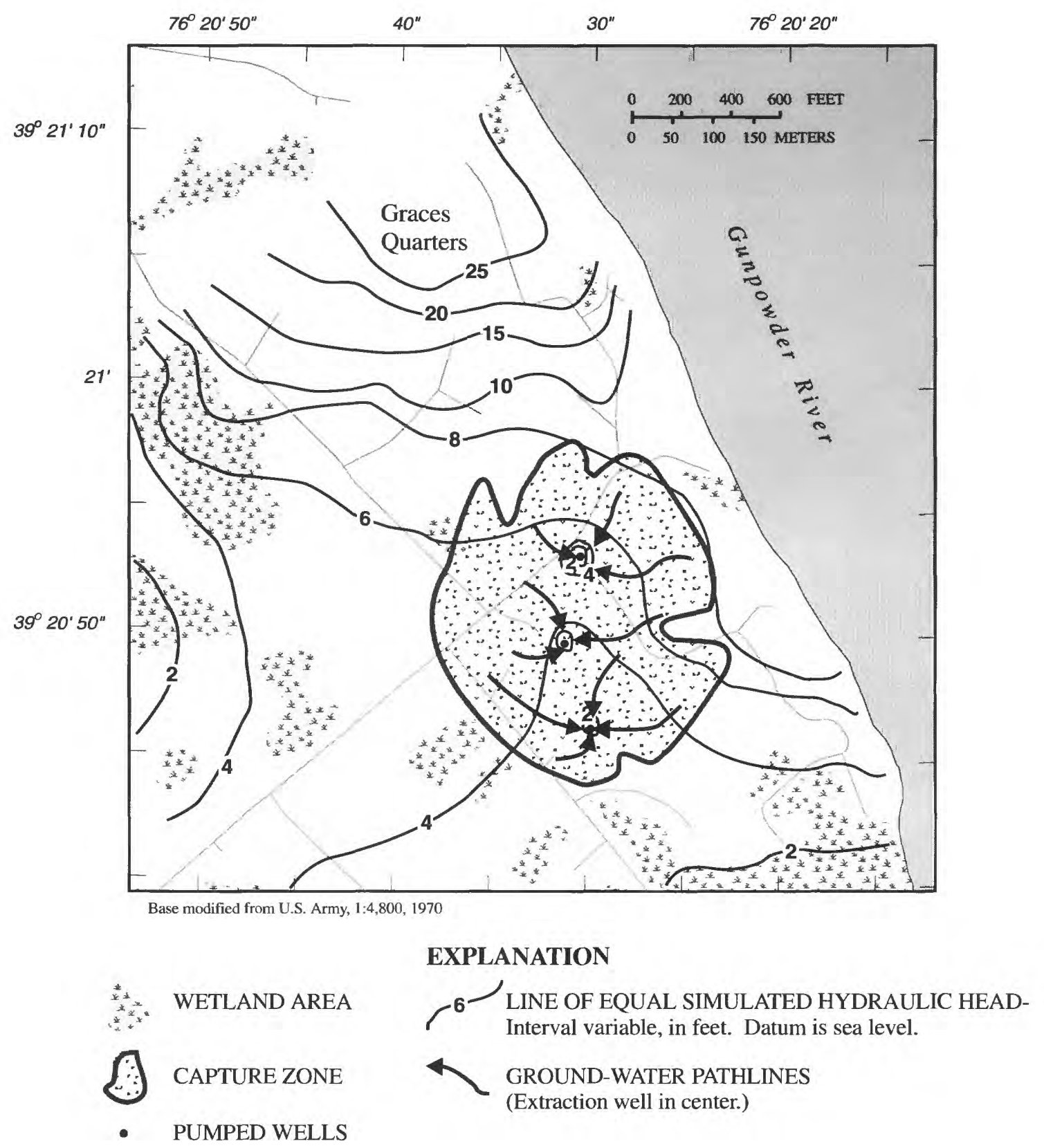

Figure 13. Location of simulated extraction wells, hydraulic head in the surficial aquifer, and ground-water pathlines for pumpage scenario 2.

A map view of the simulated capture zones for the three extraction wells from this scenario is shown in figure 13. The capture zone for each of the extraction wells in the scenario would be about $1,000 \mathrm{ft}$, in a direction normal to the axis of the three wells (fig. 13). The capture zones for the three wells would overlap if the wells were pumped at this rate, which means that hydraulic gradients within the concentrated part of the plume would be toward the extraction wells. This should prevent further migration of high concentrations of dissolved VOC's from the central plume area and allow for removal of dissolved VOC's.

\section{Scenario 3}

Scenario 3 consists of pumping $7 \mathrm{gal} / \mathrm{min}$ from each of three simulated extraction wells 
oriented in a southwest-northeast direction (fig. 11). The wells would be near the leading edge of the known VOC contaminant plume. An additional well would inject $7 \mathrm{gal} / \mathrm{min}$ into the surficial aquifer upgradient of the plume at the site of the simulated extraction well from scenario 1 (Scott Morgan, written commun., 1995). Remediation of this type could be used to prevent contaminant migration past a certain point, such as the current leading edge of the plume, and could help flush the contaminants through the system with the induced recharge.

The pumpage in scenario 3 may or may not have adverse effects on the natural hydrologic system at Graces Quarters. Simulated water levels in figure 14 indicate there would be a net discharge of ground water into the wetland that is located in

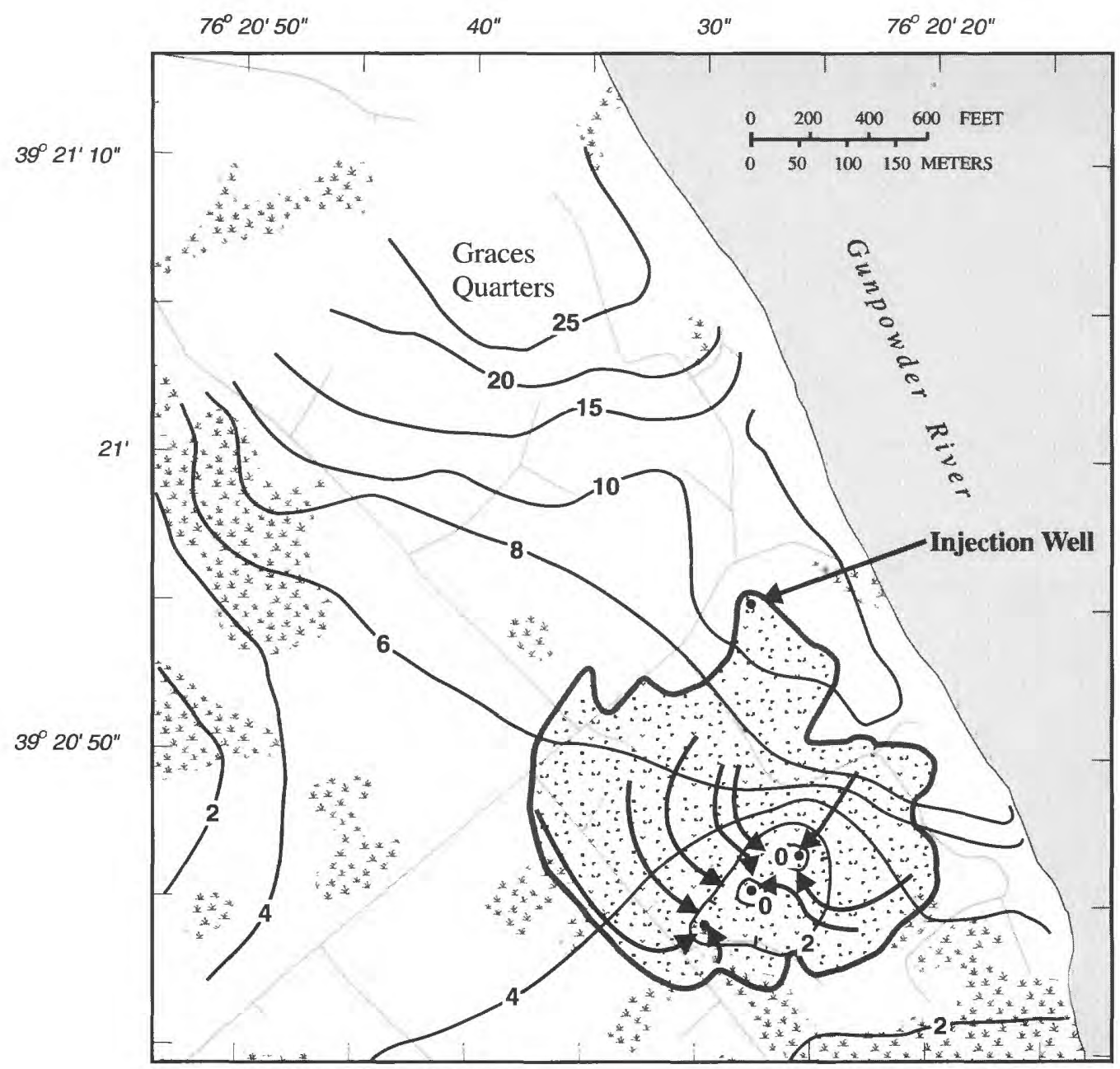

Base modified from U.S. Army, 1:4,800, 1970

EXPLANATION

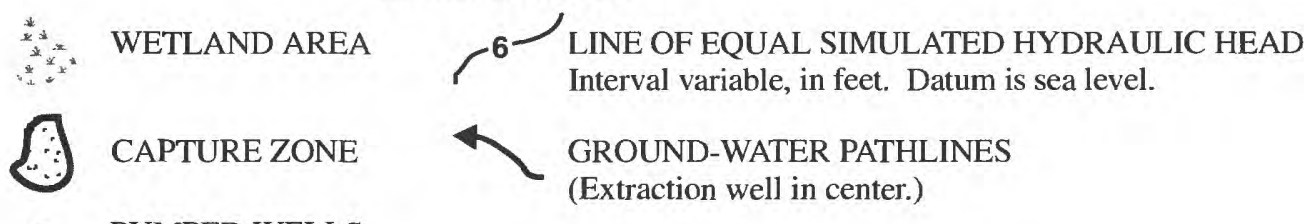

- $\quad$ PUMPED WELLS

Figure 14. Location of simulated extraction wells, hydraulic head in the surficial aquifer, and ground-water pathlines for pumpage scenario 3. 
the southern part of the figure, just as there was during unstressed conditions. However, the pumpage scenario is designed to remove $14 \mathrm{gal} / \mathrm{min}$ from the ground-water flow system $(21 \mathrm{gal} / \mathrm{min}$ pumped from extraction wells minus $7 \mathrm{gal} / \mathrm{min}$ returned into an upgradient injection well). This would be a reduction of recharge to the system of about $2,700 \mathrm{ft}^{3} / \mathrm{d}$, which is 6.5 percent of the $42,000 \mathrm{ft}^{3} / \mathrm{d}$ applied to the calibrated model. As with scenario 2, removal of this much water from the system may reduce ground-water discharge to the wetlands.

According to this scenario, the simulated remediation could be effective in preventing migration of contaminants from the current chlorinated VOC plume past the simulated extraction wells. The capture zones (fig. 14) of the three simulated extraction wells overlap, which indicates that dissolved contaminants upgradient of the wells would not be able to migrate past them. The capture zone radius along the axis of the wells (which are located normal to the axis of the plume) is about $500 \mathrm{ft}$ from the central extraction well.

\section{SUMMARY AND CONCLUSIONS}

Graces Quarters is part of the Edgewood Area of Aberdeen Proving Ground, Md., and was used as an open-air test site for chemical agents and munitions from the late 1940's to about 1971 . Activities related to testing resulted in groundwater contamination by volatile organic compounds in the east-central part of Graces Quarters. As part of the Remedial Investigation/Feasibility Study to assess this contamination, the U.S. Geological Survey designed a ground-water flow model of the Graces Quarters area. The model was used to determine ground-water flow paths and time of travel for ground water in known areas of contamination, and to determine the hydrogeologic effects of various ground-water remediation scenarios.

The hydrogeologic units identified at Graces Quarters are the surficial aquifer, upper confining unit, middle aquifer, middle confining unit, lower aquifer, and lower confining unit. The complex nature of the sediments underlying the area makes it difficult to characterize ground-water flow within the hydrogeologic units.
A finite-difference ground-water flow model and particle-tracking subroutine was used to simulate ground-water flow and potential remedial actions at Graces Quarters. The model was calibrated to steady-state conditions represented by the averaged hydraulic head from measurements in April and July 1994. In the calibrated model, the average difference between simulated and measured head in a well was about $1 \mathrm{ft}$. Recharge rates in the calibrated model ranged from 0 to $12 \mathrm{in} / \mathrm{yr}$ and recharge was distributed areally across the peninsula in zones that were determined from topographic factors and calibration adjustments. Hydraulic conductivity values ranged from 0.001 to about $50 \mathrm{ft} / \mathrm{d}$ in the surficial aquifer.

Several remedial actions for the Graces Quarters area were simulated with the calibrated ground-water model and particle-tracking subroutinc. A no-action scenario was simulated to compare flow directions and traveltimes during unstressed conditions with those during times of pumpage. Three pumpage scenarios were simulated to examine ground-water flow and capture zones for contaminants entrained in the flow. The simulations will help with decisions regarding the optimum remedial action for contaminated ground water in the surficial aquifer.

Results of the no-action scenario, which simulated advective ground-water flow under unstressed conditions, indicated that ground water from the contaminated area could discharge to a non-tidal wetland within 5 to 10 years. In this same timeframe, ground water from contaminated areas would reach the middle aquifer. Model results indicate that it would take 100 to 200 years for the ground water that has flowed into the middle aquifer to discharge back at the surface, and that ground water from the contaminated part of the surficial aquifer would not reach the lower aquifer within the 200-year simulation period.

Pumpage scenario 1 was designed to examine the effects of pumping one simulated extraction well at $7 \mathrm{gal} / \mathrm{min}$ near either the source or one of several sources of the highest concentrations of chlorinated VOC's detected in the ground water at Graces Quarters. The purpose of this type of remediation would be to reverse the hydraulic 
gradient and draw contaminants back toward their source for removal and treatment. The simulation indicated that such a remediation would not likely be successful, because the capture zone from pumping the well did not overlap all of the areas of the highest concentrations of chlorinated VOC's.

Pumpage scenario 2 was designed to examine the effects of pumping $7 \mathrm{gal} / \mathrm{min}$ from each of three simulated extraction wells. The wells would be oriented in a north-south direction along the axis of the highest detected concentrations of chlorinated VOC's. The capture zones for this scenario indicate that the hydraulic gradients within the concentrated part of the plume would be toward the extraction wells. This should prevent further migration of high concentrations of dissolved VOC's from the central plume area. However, removal of this much water from the system may reduce ground-water discharge to the wetlands.
Pumpage scenario 3 was designed to examine the effects of pumping $7 \mathrm{gal} / \mathrm{min}$ from each of three simulated extraction wells. The wells would be oriented in a southwest-northeast direction at what is perceived to be the leading edge of the VOC contaminant plume. Another well would inject $7 \mathrm{gal} / \mathrm{min}$ into the surficial aquifer at the location of the simulated extraction well from scenario 1 . The results indicate that scenario 3 could be effective in preventing migration of contaminants from the current chlorinated VOC plume past the simulated extraction wells. The capture zones of the wells would overlap, which indicates that dissolved contaminants upgradient of the wells would not be able to migrate past them. As with scenario 2, removal of this much water from the system may reduce ground-water discharge to the wetlands. 


\section{REFERENCES CITED}

Anderson, M.P., and Woessner, W.W., 1992, Applied groundwater modeling--simulation of flow and advective transport: San Diego, Academic Press, 381 p.

Bennett, R.R., and Meyer, R.R., 1952, Geology and ground-water resources of the Baltimore area: State of Maryland, Board of Natural Resources, Department of Geology, Mines and Water Resources, Bulletin 4, $573 \mathrm{p}$.

Casagrande, A., 1948, Classification and identification of soils: Transactions of the American Society of Civil Engineers, v. 113, p. 901-992.

Chapelle, F.H., 1985, Hydrogeology, digital solute-transport simulation, and geochemistry of the lower Cretaceous aquifer system near Baltimore, Maryland: Maryland Geological Survey Report of Investigations 43, 120 .

Cooper, H.H., Jr., Bredehoeft, J.D., and Papadopulos, I.S., 1967, Response of a finitediameter well to an instantaneous charge of water: Water Resources Research, v. 3, no. 1, p. 263-269.

Crowley, W.P., Reinhardt, Juergen, and Cleaves, E.T., 1976, Geologic map of Baltimore County and City, Maryland: Baltimore, Maryland Geological Survey, scale 1:62,500.

Dames \& Moore, Inc., 1993, Remedial Investigation/Feasibility Study work plan for Graces Quarters, Aberdeen Proving Ground, Maryland: Consultant's report for U.S. Army Corps of Engineers, Huntsville, Ala., v. 1, variously paged.

1995a, Graces Quarters Remedial Investigation first quarter technical memorandum, Aberdeen Proving Ground, Maryland: Consultant's report for Hazardous Waste Remedial Actions Program, Oak Ridge, Tenn., variously paged. 1995b, Graces Quarters Remedial Investigation second quarter technical memorandum, Aberdeen Proving Ground, Maryland: Consultant's report for Hazardous Waste Remedial Actions Program, Oak Ridge, Tenn., variously paged.

1995c, Graces Quarters, Aberdeen Proving Ground, Edgewood Maryland, well installation report: Consultant's report for Hazardous Waste Remedial Actions Program, Oak Ridge, Tenn., variously paged.

Domenico, P.A., and Schwartz, F.W., 1990 , Physical and chemical hydrogeology: New York, Wiley, $824 \mathrm{p}$.

Fenneman, N.M., 1938, Physiography of eastern United States: New York, McGraw-Hill, $714 \mathrm{p}$.

Ferris, J.G., 1963, Cyclic water-level fluctuations as a basis for determining aquifer transmissibility, in Bentall, Ray (compiler), Methods of determining permeability, transmissibility, and drawdown: U.S. Geological Survey Water-Supply Paper 1536-I, p. 305-318.

Fetter, C.W., 1994, Applied hydrogeology (3d ed.): New York, MacMillan, $691 \mathrm{p}$.

Freeze, R.A., and Cherry, J.A., 1979, Groundwater: Englewood Cliffs, New Jersey, Prentice-Hall, 604 p.

Ham, L.K., Tenbus, F.J., Sears, L.N., and Phillips, S.W., 1991, Hydrogeologic data for Graces Quarters, Aberdeen Proving Ground, Maryland: U.S. Geological Survey Open-File Report 91-71, $68 \mathrm{p}$.

Hazen, A., 1911, Discussion--Dams on sand foundations: Transactions, American Society of Civil Engineers, v. 13, p. 199.

Hughes, W.B., 1995, Ground-water flow and the possible effects of remedial actions at J-Field, Aberdeen Proving Ground, Maryland: U.S. Geological Survey Water-Resources Investigations Report 95-4075, $39 \mathrm{p}$. 
Hvorslev, M.J., 1951, Time lag and soil permeability in groundwater observations: Vicksburg, Mississippi, U.S. Army Corps of Engineers Waterways Experimental Station Bulletin 36, $50 \mathrm{p}$.

Johnson, A. I., 1967, Specific yield- Compilation of specific yields for various materials: U.S. Geological Survey Water-Supply Paper 1662-D, 74 p.

Lee, Keenan, and Fetter, C.W., 1994, Hydrogeology laboratory manual: New York, MacMillan, $136 \mathrm{p}$.

McDonald, M.G., and Harbaugh, A.W., 1988, A modular three-dimensional finite-difference ground-water flow model: U.S. Geological Survey Techniques of Water Resources Investigations, Book 6, Chapter A1, variously paged.

Nemeth, Gary, 1989, Resource Conservation and Recovery Act (RCRA) facility assessment, Edgewood Area, Aberdeen Proving Ground, Maryland: Aberdeen Proving Ground, Maryland, Report 39-26-0490-90, 1,158 p.

Nemeth, Gary, Murphy, J.M., Jr., and Zarzycki, J.H., 1983, Environmental survey of the Edgewood Area of Aberdeen Proving Ground, Maryland: Aberdeen Proving Ground, Maryland, Report DRXTH-AS-FR-8215, variously paged.

Otton, E.G., and Mandle, R.J., 1984, Hydrogeology of the upper Chesapeake Bay area, Maryland, with emphasis on aquifers in the Potomac Group: Maryland Geological Survey Report of Investigations 39,62 p.
Pollock, D.W., 1989, Documentation of computer programs to complete and display pathlines using results from the U.S. Geological Survey modular three-dimensional finite-difference ground-water model: U.S. Geological Survey Open-File Report 89-381, 89 p.

Tenbus, F.J., and Blomquist, J.D., 1995, Hydrogeology and water quality in the Graces Quarters area of Aberdeen Proving Ground, Maryland: U.S. Geological Survey WaterResources Investigations Report 94-4175, $115 \mathrm{p}$.

Tenbus, F.J., and Phillips, S.W., 1990, Study approach for the hydrogeologic assessment of Carroll Island and Graces Quarters, Aberdeen Proving Ground, Maryland: U.S. Geological Survey Open-File Report 90-181, 110 p.

Todd, D.K., 1980, Groundwater Hydrology (2d ed.): New York, Wiley, $535 \mathrm{p}$.

Vokes, H.E., 1957, Geography and geology of Maryland: State of Maryland. Board of Natural Resources, Department of Geology, Mines and Water Resources, Bulletin 19, $243 \mathrm{p}$.

Vroblesky, D.A., Lorah, M.M., and Oliveros, J.P., 1995, Ground-water, surface-water, and bottom-sediment contamination in the O-field area, Aberdeen Proving Ground, Maryland, and the possible effects of selected remedial actions on ground water: U.S. Geological Survey Water-Supply Paper 2399, 95 p. 